\title{
Stable-isotope time series and precipitation origin from firn-core and snow samples, Altai glaciers, Siberia
}

\author{
Vladimir B. AIZEN, ${ }^{1}$ Elena AIZEN, ${ }^{1}$ Koji FUJITA, ${ }^{2}$ Stanislav A. NIKITIN, ${ }^{3}$ \\ Karl J. KREUTZ, ${ }^{4}$ L. Nozomu TAKEUCHI ${ }^{5}$ \\ ${ }^{1}$ College of Science, University of Idaho, PO Box 443025, Moscow, Idaho 83844, USA \\ E-mail: aizen@uidaho.edu \\ ${ }^{2}$ Hydrospheric Atmospheric Research Center, Nagoya University, Nagoya 464-8601, Japan \\ ${ }^{3}$ Department of Glacio-Climatology, Tomsk State University, 634050 Tomsk, Russia \\ ${ }^{4}$ Stable Isotope Laboratory, University of Maine, 236 Sawyer ERC, Orono, Maine 04469, USA \\ ${ }^{5}$ Research Institute for Humanity and Nature, Takashima-cho 335, Kyoto 602-0878, Japan
}

\begin{abstract}
In the summers of 2001 and 2002, glacio-climatological research was performed at 4110 $4120 \mathrm{~m}$ a.s.I. on the Belukha snow/firn plateau, Siberian Altai. Hundreds of samples from snow pits and a $21 \mathrm{~m}$ snow/firn core were collected to establish the annual/seasonal/monthly depth-accumulation scale, based on stable-isotope records, stratigraphic analyses and meteorological and synoptic data. The fluctuations of water stable-isotope records show well-preserved seasonal variations. The $\delta^{18} \mathrm{O}$ and $\delta \mathrm{D}$ relationships in precipitation, snow pits and the snow/firn core have the same slope to the covariance as that of the global meteoric water line. The origins of precipitation nourishing the Belukha plateau were determined based on clustering analysis of $\delta^{18} \mathrm{O}$ and $\mathrm{d}$-excess records and examination of synoptic atmospheric patterns. Calibration and validation of the developed clusters occurred at event and monthly timescales with about $15 \%$ uncertainty. Two distinct moisture sources were shown: oceanic sources with d-excess $<12 \%$, and the Aral-Caspian closed drainage basin sources with d-excess $>12 \%$. Two-thirds of the annual accumulation was from oceanic precipitation, of which more than half had isotopic ratios corresponding to moisture evaporated over the Atlantic Ocean. Precipitation from the Arctic/Pacific Ocean had the lowest deuterium excess, contributing one-tenth to annual accumulation.
\end{abstract}

\section{INTRODUCTION}

The available spatial coverage of snow, firn and ice records is inadequate to document climatic and environmental change over the vast Asian continent. However, environmental records from the northwestern periphery of the central Asian mountain system (CAMS), obtained from Tien Shan firn/ice cores (Kreutz and others, 2001, 2003; Aizen and others, 2004) and snow/firn-core records from alpine areas in Siberia (Olivier and others, 2003; Aizen and others, in press), are extending the area of climatic and environmental analyses in Asia.

The research reported here focuses on the Siberian Altai, the most continental northern periphery of the CAMS and the southern periphery of the Asian Arctic basin (Fig. 1). It is an ideal area for the analysis of climatic records relating to the major northern Eurasian circulation systems, i.e. the westerly jet stream and the Siberian high. Altai glaciers, located at the center of the Eurasian continent, provide records on the advection of fresh water transported from the Atlantic and Pacific Oceans to the Arctic Ocean (Fig. 1). Firn records from the Altai glaciers can also be associated directly with the large Aral-Caspian internal water system, with moisture transferred from this closed Asian drainage basin to the great Siberian river basins. The Atlantic, Arctic and Pacific Oceans are considered external moisture sources for the Siberian Altai. Internal moisture sources refer to evaporation from continental sources, such as the closed Aral and Caspian drainage basins, or convection from local basins, subjected to stronger kinetic effects and greater continental recycling. In the analyses, moisture transferred from the eastern Black Sea to the Altai mountains is also considered as evaporated from an internal moisture source. Thus, Altai glaciers store unique information on climate dynamics and on the internal and external hydrological cycles of northern Eurasia.

Data on the stable-isotope content in precipitation and firn core have contributed to our understanding of environmental signals from different regions of the globe (Friedman and others, 1964; Johnsen, 1977; Yao and Thompson, 1992; Dansgaard and others, 1993; Thompson and others, 1995; Aizen and others, 1996, 2004; Jouzel and others, 1997; Yao and others, 1999; Welker, 2000; Froehlich and others, 2002; Naftz and others, 2002). In general, the main controls affecting the stable-isotope content in snow, firn and ice are the atmospheric deposition conditions, especially temperature, and the associated air-mass trajectories and source regions. The overall levels and seasonal fluctuations of the $\delta^{18} \mathrm{O}$ and $\delta \mathrm{D}$ relationship provide insight into changes in the hydrologic cycle and have been used as a climatic indicator in ice-core records (Hammer and others, 1978; Jouzel and others, 1994; Petit and others, 1999; Vimeux and others, 1999) and in isotopic modeling of atmospheric processes (Ciais and Jouzel, 1994; Hoffmann and others, 2000; Tian and others, 2001).

The main objective of this research is to determine the physical processes controlling the $\delta^{18} \mathrm{O}$ and $\delta \mathrm{D}$ stableisotope content recorded in the Altai glaciers and to couple these records with the precipitation-origin time series through analysis of synoptic-scale atmospheric dynamics. 

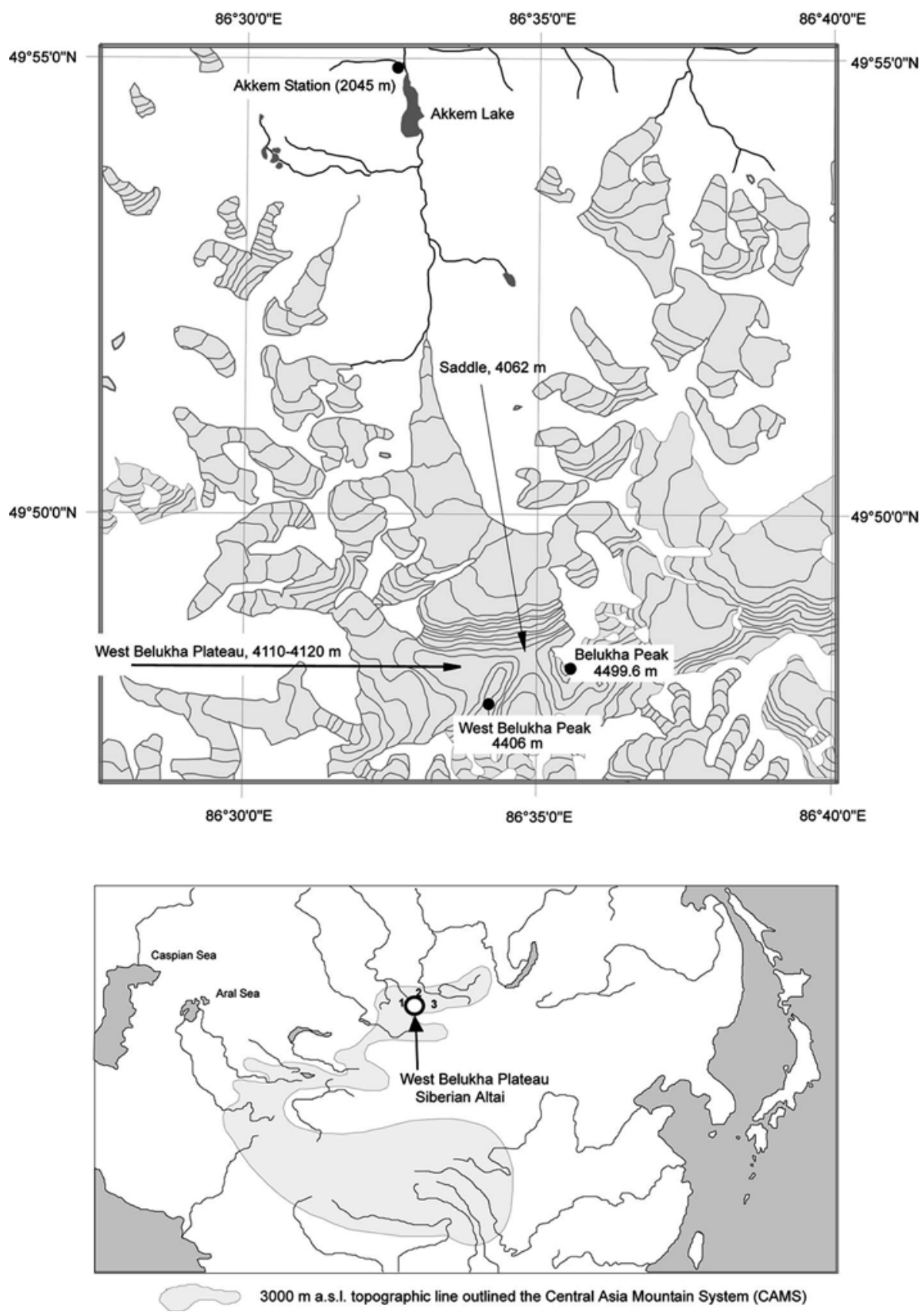

Fig. 1. Map of the research area. Meteorological stations are numbered: 1. Kara-Turek; 2. Akkem; 3. Aktru.

Information on the distribution of stable isotopes in firn cores from the Siberian Altai can be used to evaluate the contribution of water vapor, associated with external and internal water cycles, to snow accumulation over the northern periphery of the CAMS.

\section{LONG-TERM DATA}

For our climatic analysis, we used 50 year long-term meteorological data from the Akkem $\left(49^{\circ} 54^{\prime} \mathrm{N}, 86^{\circ} 32^{\prime} \mathrm{E}\right.$; 2045 m a.s.I.), Kara-Turek ( $49^{\circ} 57^{\prime} \mathrm{N}, 86^{\circ} 29^{\prime} \mathrm{E} ; 2600 \mathrm{~m}$ a.s.I.) and Aktru (50 $5^{\circ} \mathrm{N}, 87^{\circ} 46^{\prime} \mathrm{E} ; 2110 \mathrm{~m}$ a.s.l.) stations, respectively located 10, 15 and $30 \mathrm{~km}$ north, northwest and northeast of the Belukha snow/firn plateau. Data from these stations have the highest correlation with air temperature and precipitation at Altai glaciers (Galakhov, 1981). All meteorological data were checked for homogeneity, inspected for the presence of random errors and plotted for periods with missing observations, following recommendations by Easterling and others (1995).

To describe atmospheric circulation patterns over southwestern Siberia that influence regional precipitation regimes at seasonal timescales, we used monthly data on the frequency of synoptic patterns observed in the Altai mountains developed by Popova (1972) and Narojniy and others (1993), and partially presented in the Central Asia Data Base completed and maintained by authors at the University of Idaho. Daily data begin from 1954, and generalize information derived from daily synoptic maps that include 2500 elementary circulation patterns. As a result, eight types of macro-synoptic processes for the Siberian Altai were identified (see Appendix). The derived classification was based on the probability of different synoptic conditions tracking the main troposphere airflows 

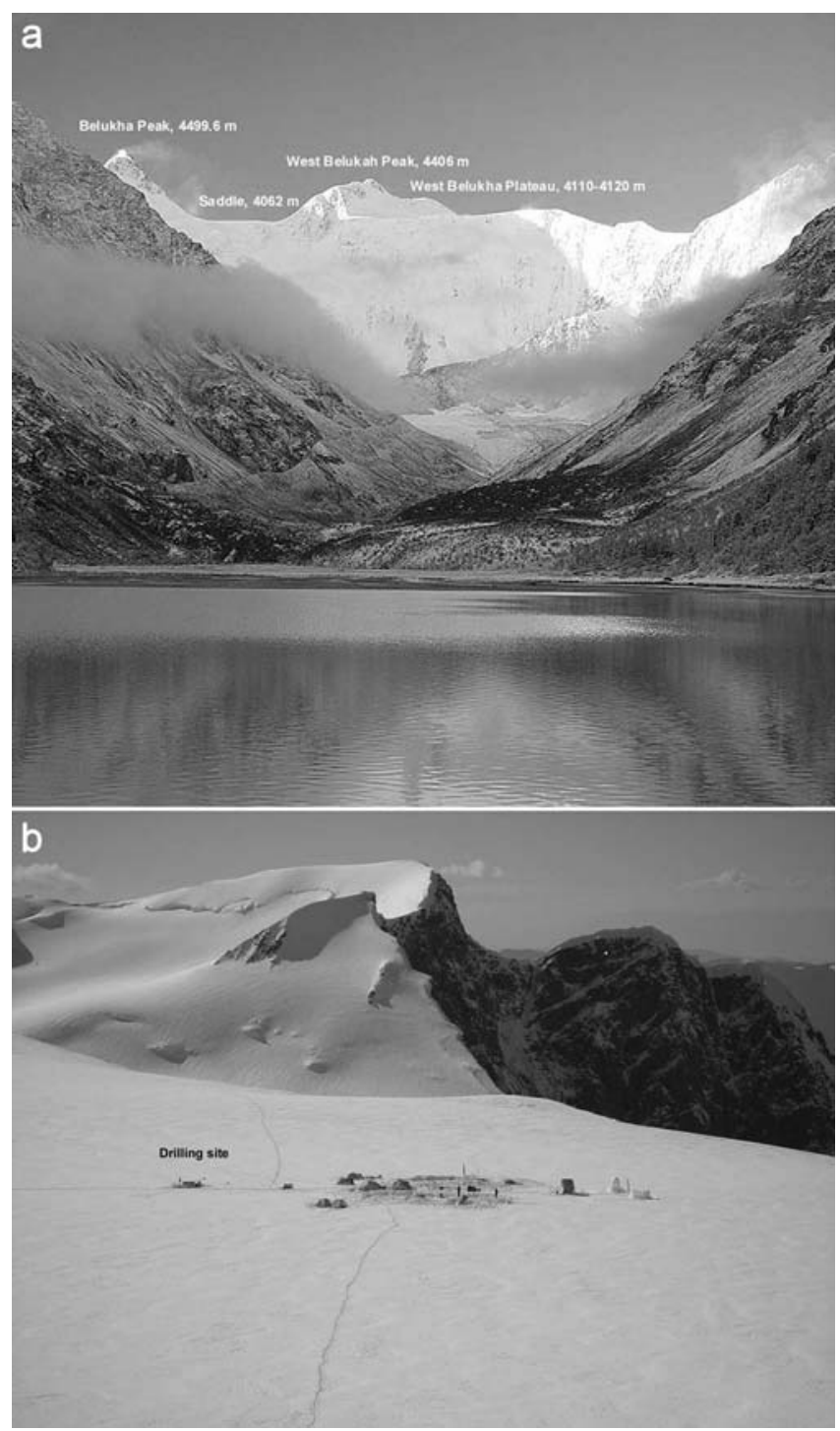

Fig. 2. (a) View from Akkem lake and meteorological station to the Belukha massif. (b) The drill site, west Belukha plateau (4115 m), Siberian Altai. Photo by V. Aizen, August 2003.

(e.g. cyclonic and anticyclonic currents over the surface and at the 500 mbar level). A similar classification developed for central Asia is presented in Aizen and others (2004).

\section{FIELD MEASUREMENTS}

The west Belukha plateau (Figs 1 and 2) is the only Siberian location where the Altai glaciers have sufficiently cold temperatures and enough snow accumulation to preserve climatic and environmental records that are unaffected by meltwater percolation. The west Belukha snow/firn plateau is in the cold recrystallization zone where positive temperatures were never observed at the drill site (4100 ma.s.I.). There is no record of positive air temperatures near the drill site during 2000/01, as measured every 3 hours using a Grant Instruments automatic weather station (Fig. 3).

The long-term average monthly air temperature at the drill-site altitude was calculated from linear extrapolation of Akkem station air temperatures with mean altitudinal gradients, and demonstrates the regime of negative air temperatures (Fig. 4a). The spring, summer, autumn and winter mean

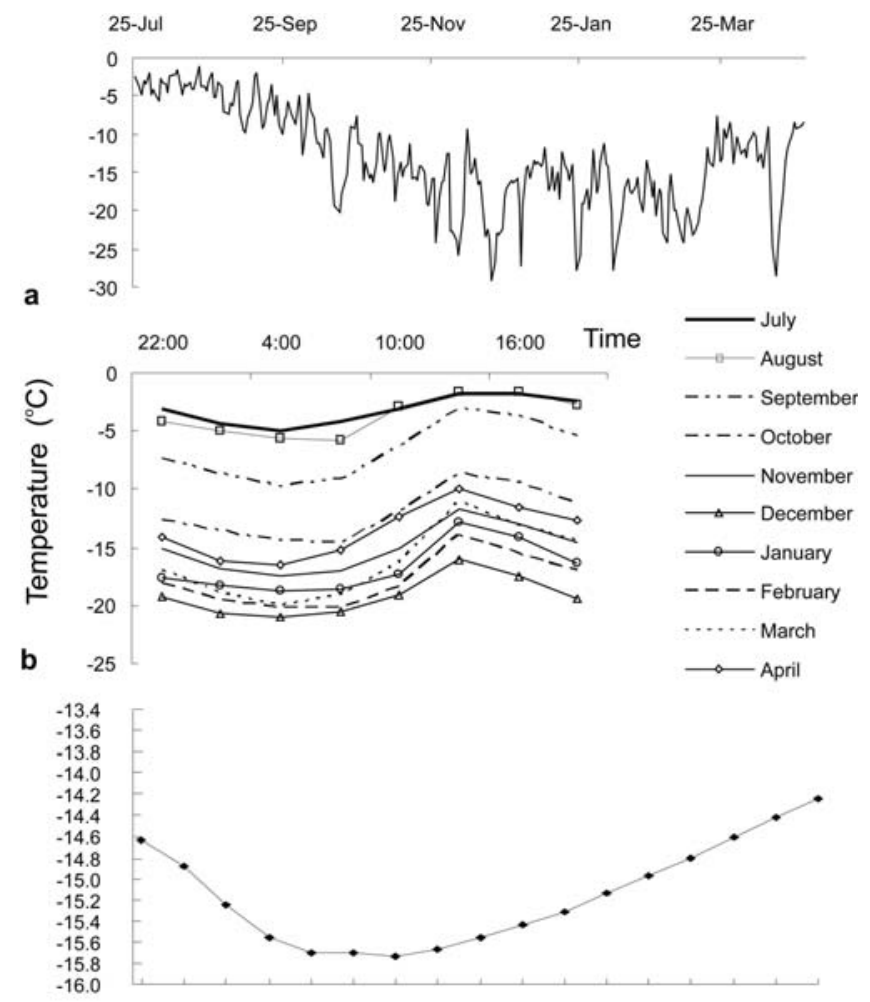

c

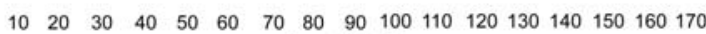
$\operatorname{Depth}(\mathrm{m})$

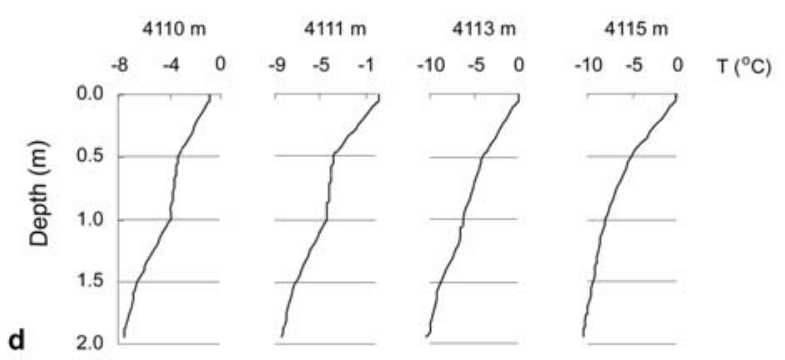

Fig. 3. (a, b) Diurnal (a) and monthly (b) mean air temperatures on the west Belukha snow/firn plateau measured by automatic weather station, July 2002-April 2003. (c) Borehole temperature profile, August 2003. (d) Snow-pit temperatures.

altitudinal gradients of air temperatures $(6.8,7.2,3.9$ and $2.1^{\circ} \mathrm{C} 10^{-3} \mathrm{~m}^{-1}$ ) were calculated using long-term data from Akkem, Kara-Turek and Aktru stations.

Snow/firn/ice temperatures were measured every $10 \mathrm{~m}$ in the $170 \mathrm{~m}$ borehole at $4115 \mathrm{~m}$ a.s.I. (Fig. 3c), and every $3 \mathrm{~cm}$ in the snow pit (Fig. 3d) using electric sensors. The lower temperatures in ice than in air indicated the non-existence of melt. From $0^{\circ} \mathrm{C}$ at the snow surface, temperature dropped to $-10^{\circ} \mathrm{C}$ at $2 \mathrm{~m}$ depth (Fig. $3 \mathrm{~d}$ ), to $-15.8^{\circ} \mathrm{C}$ at $50-70 \mathrm{~m}$ depth and to $-14.2^{\circ} \mathrm{C}$ at the bottom (Fig. 3c), lower than the annual mean air temperature at this elevation $\left(\bar{T}_{\text {air }(1984-2000)}=\right.$ $-10.2^{\circ} \mathrm{C}$; see Table 1$)$.

The melt index (Koerner and Fisher, 1990) compiled from the measured $5 \mathrm{~cm}$ density data (Fig. $5 \mathrm{~d}$ ), and the analyzed stratigraphy (Fig. 6) showed $<5 \%$ of melt caused by solar radiation at air temperatures close to zero (Fig. 3). This minimal melt may form thin ice crusts and ice lenses on the snow surface but is insufficient to penetrate downward (Fig. 6).

The drill site selected by a Swiss team (Olivier and others, 2003), on the saddle (4062 m a.s.l.) of a narrow field 

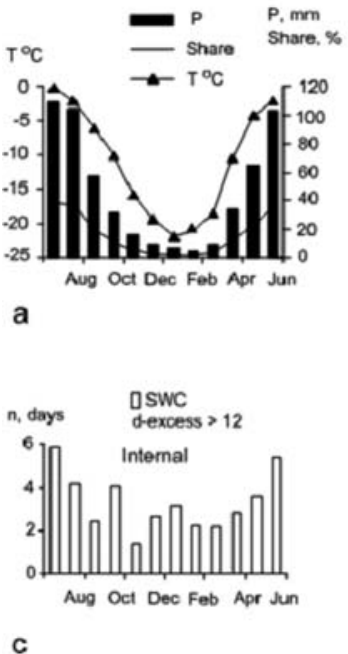
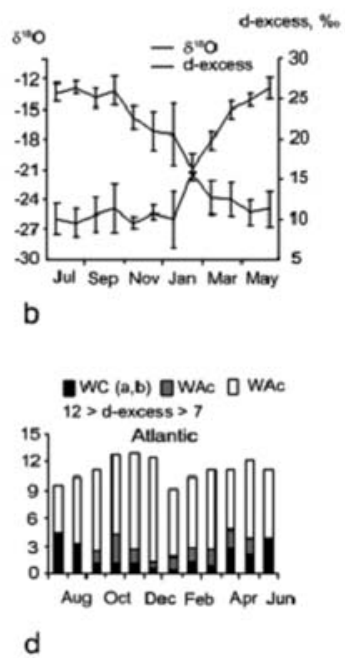

d

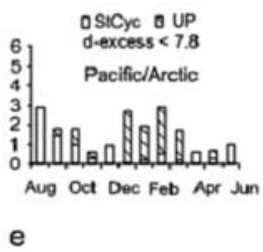

Fig. 4. (a) Long-term monthly means of air temperature at the drill site, precipitation and share/fraction of monthly precipitation in annual total at Akkem station. (b) Long-term monthly means and standard deviations of $\delta^{18} \mathrm{O}$ and d-excess averaged from Altai snow/firn-core records, 1984-2001. (c-e) Long-term mean number of days with different synoptic patterns: southwest cyclones (c); western cyclones and western anticyclone (d); and stationary cyclones/ultra-polar intrusion (e). between the Belukha (4499 ma.s.l.) and west Belukha (4406 ma.s.l.) peaks (Figs 1 and 2), is lower and warmer. Furthermore, because of very strong snow and wind redistribution, particularly in the winter between the two peaks, the saddle is not as suitable for snow/firn-core records as the west Belukha plateau, where seasonal $\delta^{18} \mathrm{O}$ and $\delta \mathrm{D}$ signals (Fig. 5a and b) are better preserved.

In the summers of 2001 and 2002, snow samples were collected every $3-5 \mathrm{~cm}$ from five $2-3 \mathrm{~m}$ snow pits and one $7.0 \mathrm{~m}$ snow pit from the Belukha snow/firn plateau (4110$4120 \mathrm{~m}$ a.s.l.). A $21 \mathrm{~m}$ snow/firn core was recovered at 4115 ma.s.l. $\left(49^{\circ} 48^{\prime} \mathrm{N}, 86^{\circ} 33^{\prime} \mathrm{E}\right)$, where radio-echo sounding indicated the ice was about $176 \mathrm{~m}$ thick (Fig. 7). Snowpit, precipitation and fresh snow samples were collected into pre-cleaned plastic bottles. The density of fresh snow and snow pits was measured at $5 \mathrm{~cm}$ intervals using a $100 \mathrm{~cm}^{3}$ stainless-steel sampler. The firn core $(19 \mathrm{~m}$ long, $9.5 \mathrm{~cm}$ in diameter) was extracted from the bottom of the $220 \mathrm{~cm}$ snow pit with a Polar Ice Coring Office (PICO) fiberglass auger. The diameter, length and weight of each recovered core section were measured to calculate density. Firn-core sections, sealed in pre-cleaned polyethylene bags, were packed into insulated shipping containers and delivered to the Japanese National Institute of Polar Research (NIPR), Tokyo.

Five stakes and benchmarks were installed for location measurements by precise global positioning system (GPS) during summer field seasons on Belukha glacier (2001: GP-SX1, TOPCON; 2002: Allstar, CMC Electronics). An automatic snow-depth gauge was installed at stake 2 on 18 July 2001 (KADEC-SNOW, KONA system). The sensor detected snow and open air using photo-diodes in increments/declines of $1 \mathrm{~cm}$ to 26 October 2001. The surface

Table 1. Mean annual and seasonal oxygen and deuterium isotope ratios and deuterium excess in firn/ice-core (f/iC), snow-pit (snP) and precipitation (Pr) records from the Belukha plateau, the Altai and other glaciers and sites along the northern periphery of central Asia

\begin{tabular}{|c|c|c|c|c|c|c|c|c|c|c|}
\hline \multirow[t]{2}{*}{ Station/glacier } & \multirow[t]{2}{*}{$\begin{array}{l}\text { Sample } \\
\text { from }\end{array}$} & \multirow[t]{2}{*}{ Period } & \multirow{2}{*}{$\begin{array}{l}P(\text { share }) \\
\text { mm }(\%)\end{array}$} & \multirow{2}{*}{$\begin{array}{l}\mathrm{T} \\
{ }^{\circ} \mathrm{C}\end{array}$} & \multirow{2}{*}{$\begin{array}{c}\delta^{18} \mathrm{O} \\
\% 0\end{array}$} & \multirow{2}{*}{$\begin{array}{l}\delta \mathrm{D} \\
\% 0\end{array}$} & \multirow{2}{*}{$\begin{array}{c}\text { d-excess } \\
\%\end{array}$} & \multirow{2}{*}{$\begin{array}{l}\Delta T \\
{ }^{\circ} \mathrm{C}\end{array}$} & \multirow{2}{*}{$\begin{array}{c}\Delta \delta^{18} \mathrm{O} \\
\%\end{array}$} & \multirow{2}{*}{$\begin{array}{l}\Delta \mathrm{d} \\
\% 0\end{array}$} \\
\hline & & & & & & & & & & \\
\hline \multirow{6}{*}{$\begin{array}{l}\text { Belukha plateau, Altai } \\
\text { ( } 4115 \text { m a.s.l.) }\end{array}$} & \multirow[t]{3}{*}{$\mathrm{f} / \mathrm{iC}$} & June 1984-July 2000 & 690 & $-10 . .2$ & -13.6 & -98.14 & 10.93 & 31.0 & 10.8 & 27.9 \\
\hline & & May-Sept & $590(83)$ & -1.74 & -13.4 & -97.27 & 10.32 & 8.9 & 8.8 & 23.9 \\
\hline & & Oct-Apr & $100(17)$ & -14.8 & -15.3 & -108.64 & 12.41 & 23.0 & 9.9 & 25.8 \\
\hline & \multirow[t]{3}{*}{$\mathrm{snP}$} & July 2000-July 2001 & 826 & -9.7 & -13.8 & -100.9 & 10.0 & 25.4 & 16.6 & 16.6 \\
\hline & & May-Sept & 595 & -1.5 & -12.2 & -87.6 & 10.2 & 5.1 & 3.4 & 5.1 \\
\hline & & Oct-Apr & 233 & -16.7 & -17.7 & -98.7 & 11.3 & 14.1 & 16.6 & 16.6 \\
\hline \multirow{3}{*}{$\begin{array}{l}\text { Inylchek, Tien Shan } \\
(5100 \text { ma.s.l.)* }\end{array}$} & \multirow[t]{3}{*}{$\mathrm{f} / \mathrm{iC}$} & 1994-2000 & 1100 & -12.3 & -16.04 & -105.3 & 23 & 33 & 10.2 & \\
\hline & & May-Sept & $800(72)$ & -4.1 & -11.56 & -80.1 & 12.4 & & & \\
\hline & & Oct-Apr & $300(28)$ & -16.5 & -21.78 & -145.8 & 28.4 & & & \\
\hline $\begin{array}{l}\text { Omsk, western Siberia } \\
(94 \text { ma.s.l. })^{\dagger}\end{array}$ & $\operatorname{Pr}$ & Year & 401 & 7.6 & -13.46 & -98.2 & 8.9 & & & \\
\hline \multirow{2}{*}{$\begin{array}{l}\text { Novosibirsk, western Siberia } \\
(162 \text { m a.s.l. })^{\dagger}\end{array}$} & \multirow{2}{*}{$\operatorname{Pr}$} & May-Oct & $295(70)$ & 12.2 & -12.49 & -85.8 & 14.1 & & 6.68 & \\
\hline & & Nov-Apr & $128(30)$ & -10.1 & -19.17 & -142.3 & 11.1 & & & \\
\hline \multirow{3}{*}{$\begin{array}{l}\text { Irkutsk, eastern Siberia } \\
(485 \text { m a.s.l. })^{\dagger}\end{array}$} & \multirow[t]{3}{*}{$\operatorname{Pr}$} & Year & 445 & 0.0 & -12.12 & -92.9 & 4.1 & & & \\
\hline & & May-Oct & $376(82)$ & 11.1 & -11.65 & -90.3 & 3.0 & & 4.48 & \\
\hline & & Nov-Apr & 84 (18) & -10.9 & -16.13 & -122.9 & 6.2 & & & \\
\hline \multirow{3}{*}{$\begin{array}{l}\text { Enisejsk, eastern Siberia } \\
(98 \mathrm{ma.s.l.})^{\dagger}\end{array}$} & \multirow[t]{3}{*}{$\operatorname{Pr}$} & Year & 491 & -1.5 & -13.29 & -98.4 & 7.9 & & & \\
\hline & & May-Oct & $312(64)$ & 10.4 & -11.86 & -84.8 & 10.1 & & 5.78 & \\
\hline & & Nov-Apr & $177(36)$ & -12.8 & -17.6 & -138.3 & 2.8 & & & \\
\hline
\end{tabular}

Note: $P$ is amount of precipitation; $T$ is mean air temperature calculated with altitudinal gradient; $\Delta T$ is absolute air-temperature amplitude; $\Delta \delta^{18} \mathrm{O}$ and $\Delta \mathrm{d}$ are respectively oxygen isotope and $\mathrm{d}$-excess range between monthly mean extremes.

*Aizen and others (in press); ${ }^{\dagger}$ Araguás-Araguás and others (1998). 


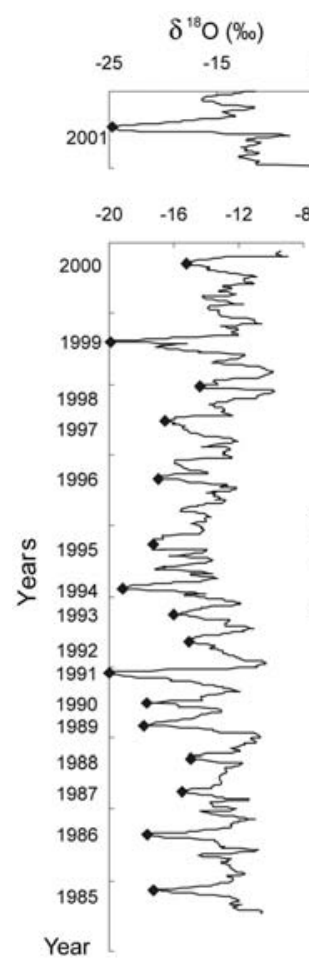

a
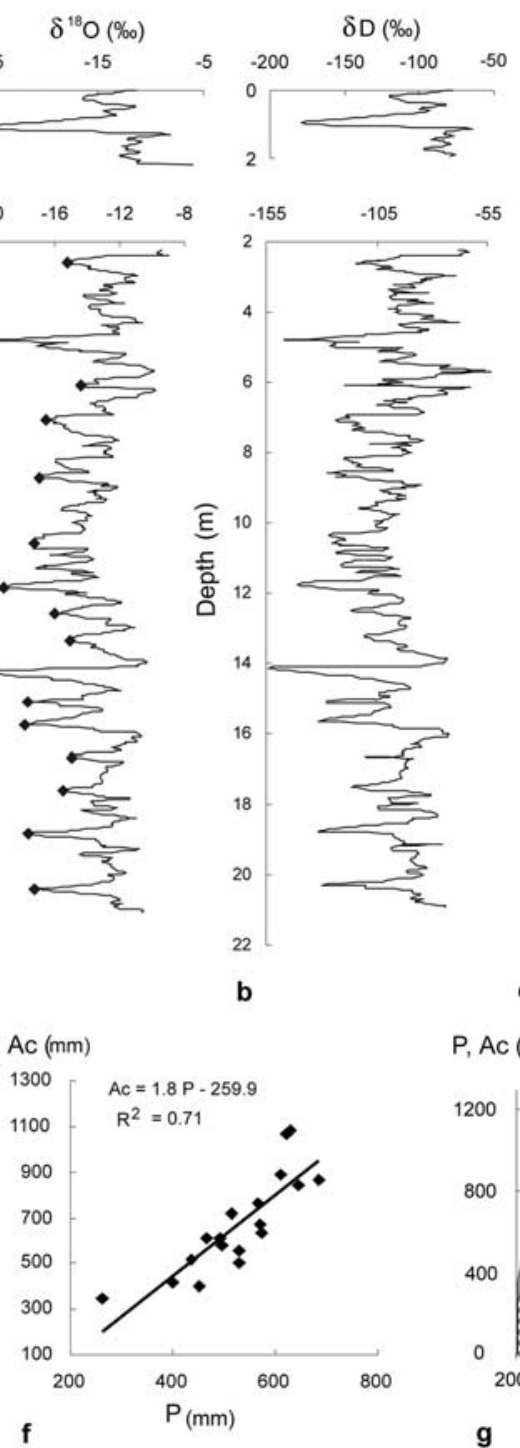

c
$\mathrm{SO}_{4}^{-2} \delta \mathrm{Eq} \mathrm{L}^{-1} \quad \rho\left(\mathrm{g} \mathrm{cm}^{3}\right) \quad \Sigma \mathrm{Ac}(\mathrm{mm})$

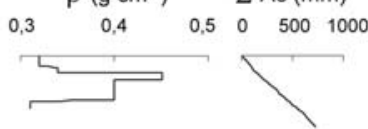

010203040506070

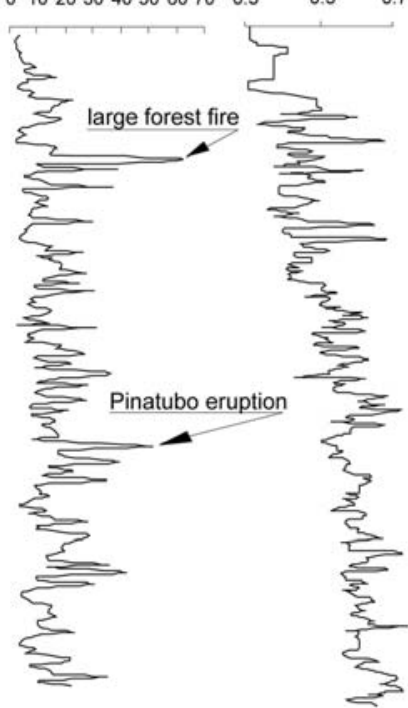

10000

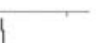

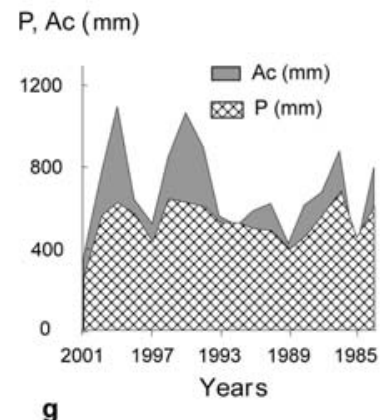

Fig. 5. (a-e) Isotopic composition in the snow/firn core: $\delta^{18} \mathrm{O}(\mathrm{a}) ; \delta \mathrm{D}(\mathrm{b})$; sulfate content $\mathrm{SO}_{4}{ }^{2-}(\mathrm{c})$; snow/firn density, $\rho$ (d); and cumulative snow water equivalent, $\Sigma A c(e)$. (f) Correlation between annual accumulation (Ac) records from firn/ice core and precipitation, $P$, at Akkem station. (g) Annual accumulation records from snow/firn core and precipitation at Akkem station. Years (1984-2001) represent winter intervals.

level was measured twice daily, in the morning and evening (Fig. 8). Daily snow accumulation (snow water equivalent (SWE) in mm; Equation (1)) was computed based on positive changes in the snow surface level $(\Delta H$ in $\mathrm{cm})$ and assuming a density of new snow $(\rho)$ of $0.22 \mathrm{~g} \mathrm{~cm}^{-3}$ (Fig. 6c). Negative or zero values of $\Delta h$ observed during snow sinking were considered as absence of daily snow accumulation.

$$
\mathrm{SWE}_{\mathrm{ds}}=10\left(\Delta h_{\mathrm{m}}+\Delta h_{\mathrm{e}}\right) \rho \text { if } \Delta h>0,
$$

where $\Delta h_{\mathrm{m}}$ and $\Delta h_{\mathrm{e}}$ are positive differences of morning/ evening and evening/morning changes in snow surface level; 10 is the unit transfer coefficient.

\section{LABORATORY ANALYSIS}

The Altai cores were processed in a dedicated cold room at NIPR using techniques established for ultra-clean sample preparation. Frozen $18 \mathrm{~m} \Omega$ water blanks were passed through the entire system to ensure there was no contamination, and for quality control. Each $3-5 \mathrm{~cm}$ of the upper $11 \mathrm{~m}$ of the snow/firn core, as well as samples from five snow pits, and fresh snow, were analyzed for $\delta^{18} \mathrm{O}$ and $\delta \mathrm{D}$ at NIPR. The bottom $10 \mathrm{~m}$ of the core was analyzed for $\delta \mathrm{D}$ at the University of Maine and for $\delta^{18} \mathrm{O}$ at the University of Idaho. Oxygen isotope ratios were measured using the standard $\mathrm{CO}_{2}$ equilibration technique (Craig, 1957). Hydrogen isotope ratios were measured using $\mathrm{Cr}$ reduction in a continuous flow system (Morrison and others, 2001). Data are reported in standard delta $(\delta)$ notation vs Standard Mean Ocean Water (SMOW). The analytical precision for measurements of oxygen and deuterium isotope ratio was $\pm 0.05 \%$ and $\pm 0.5 \%$ respectively. Analytic uncertainty in $\mathrm{d}$-excess was estimated at

$$
U(\mathrm{~d})=\left[(u \delta \mathrm{D})^{2}+8\left(u \delta^{2} \mathrm{O}\right)^{2}\right]^{1 / 2}=0.52 \%
$$

which is mainly dependent on the analytical precision of deuterium. The technique of snow/firn-core stable-isotope analysis has been described by Kreutz and others (2001).

The concentration of sulfate was measured at NIPR by ion chromatography (Dionex 500 using AS14 separation column and conductivity detection). To examine the temporal 


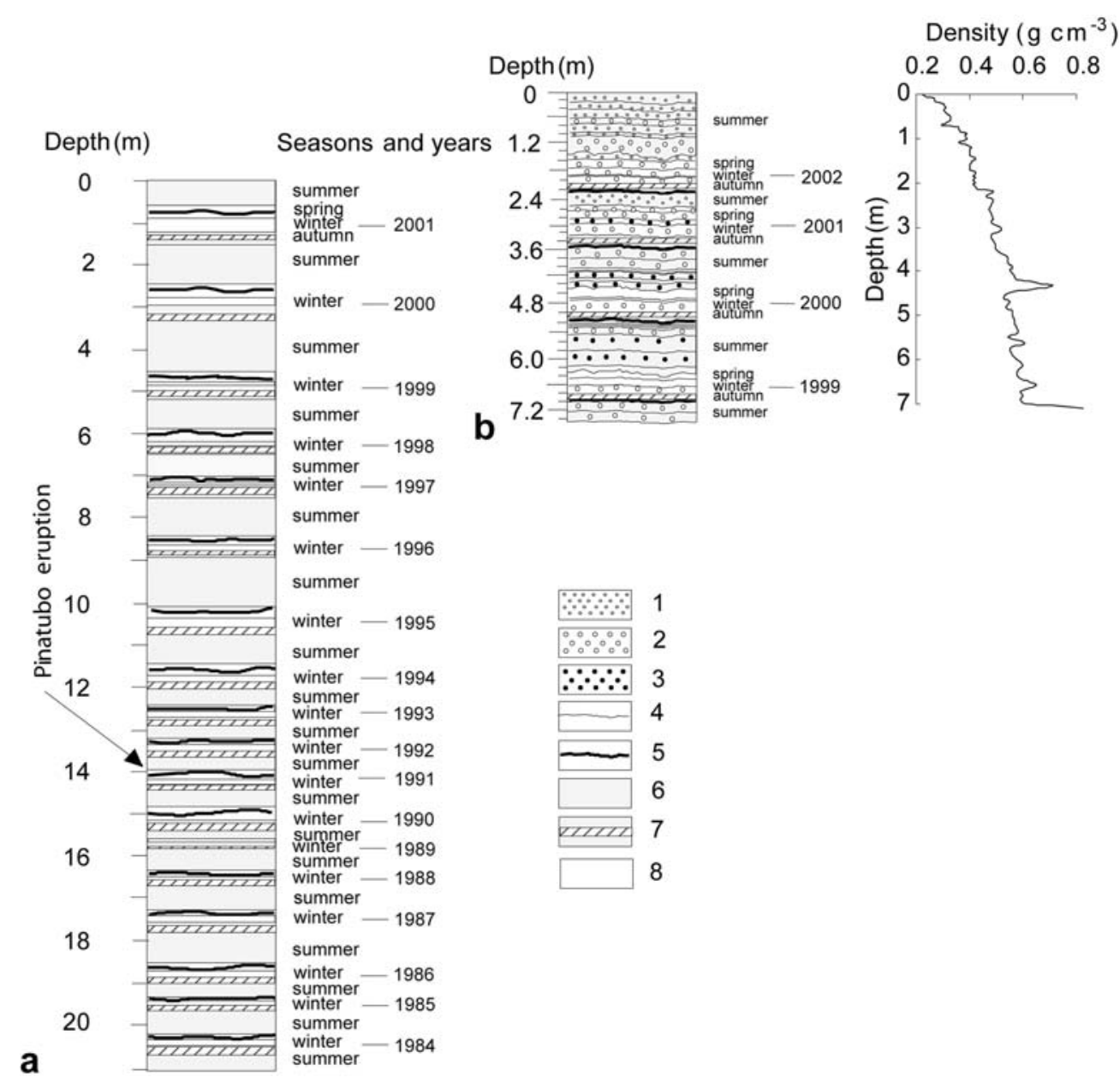

Fig. 6. Stratigraphy of $21 \mathrm{~m}$ snow/firn core recovered in 2001 (a), and stratigraphy (b) and snow/firn density (c) of $7 \mathrm{~m}$ snow/firn pit dug in 2002 from the west Belukha plateau with seasonal and annual-layer identification: 1. fine-grained snow/firn; 2. medium-grained snow/firn; 3. coarse-grained snow/firn; 4. 1-2 mm radiation of wind ice crusts; 5 . ice lenses or ice layers up to $5 \mathrm{~mm}$ thick; 6 . regelate snow/firn; 7 . finegrained snow/firn with aeolian particles; 8 . compact white snow/firn.

modes of variation in the stable-isotope records obtained from the snow/firn core, regression, spectral and K-mean clustering analyses (SYSTAT version 9 (SPSS Inc.)) were used.

\section{RESULTS}

\subsection{Establishing a depth-age relationship}

No significant post-depositional effects were apparent in the oxygen and hydrogen records from the firn core, as the amplitude of the signal near the bottom of the core was similar to that observed near the surface (Fig. $5 a$ and b). To determine annual snow accumulation layers, we used stable-isotope records with existing, well-preserved seasonal $\delta^{18} \mathrm{O}$ and $\delta \mathrm{D}$ signals (Fig. 5a and b), visible seasonal accumulation evidence in snow/firn stratigraphy (Fig. 6) and annual precipitation data from Akkem station (Fig. $5 f$ and g). Identification of annual accumulation layers in the snow/firn core was based on the extreme values of $\delta^{18} \mathrm{O}$ and $\delta \mathrm{D}$, as minimum winter and maximum summer air temperatures are a distinctive characteristic of the Altai meteorological regime (Fig. 4a). In cases of double isotopic peaks during the warm seasons of 1984, 1985, 1994, 1996 and 1998 (Fig. 5a and b), visible seasonal accumulation evidence in snow/firn stratigraphy (Fig. 6) was used as the basis of dating, with corresponding annual accumulation compared to annual precipitation data from Akkem station for these years.
Snow and firn-ice densities (Fig. 5d) were used to establish cumulative depth/water-equivalent profiles (Fig. 5e). The correlation between annual accumulation layers in the snow/firn core and precipitation at Akkem station reached 0.82 (Fig. $5 f$ and g). The mean annual accumulation rate calculated at the drill site was $690 \mathrm{~mm}$ w.e. $\mathrm{a}^{-1}$ from summer 1984 to summer 2001; this agrees with the calculated accumulation rates presented in the World Atlas of Snow and Ice Resources (Kotlyakov, 1997) and with the rate of annual net accumulation obtained and validated through tritium and ${ }^{210} \mathrm{~Pb}$ records by Olivier and others (2003).

To verify the core chronology, we used the marker horizon of the Pinatubo (Philippines) volcanic eruption of June 1991 (Soden and others, 2002). The ice layers of volcanic origin have been deduced from acidity measurements (mainly $\mathrm{H}_{2} \mathrm{SO}_{4}$ ) along firn/ice cores (Zielinski and others, 1996; Clausen and others, 1997; Schwander and others, 2001; De Angelis and others, 2003). The sulfate profile of the firn core reported in Figure $5 \mathrm{c}$ indicated two spikes in the $\mathrm{SO}_{4}{ }^{2-}$ outside the regular seasonal variations. The strong peak of $50.88 \mu \mathrm{EL}^{-1}$ measured at $14.01 \mathrm{~m}$ corresponds to summer 1991 (Figs 5c and 6), documenting the Pinatubo eruption. The second sulfate peak at $5.8-6.0 \mathrm{~m}$ is associated with the large forest fire that occurred in Siberia in 1998. 


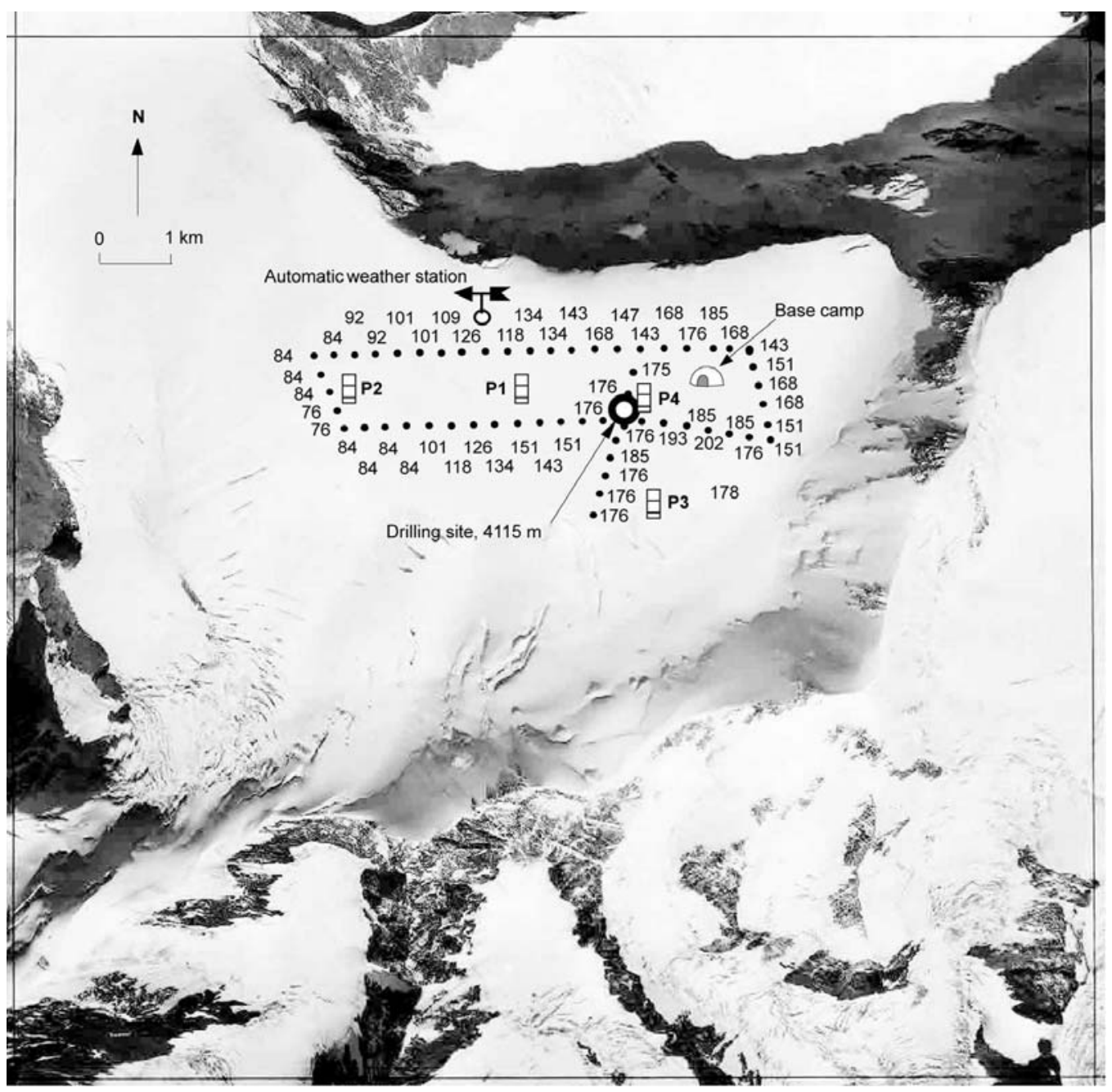

Fig. 7. Ice-thickness profiles, snow pits, the weather station and snow/firn drill site on the west Belukha plateau, projected onto an aerial photograph.

In addition, to validate the 17 annual accumulation layers identified in the snow/firn core, we used single series Fourier analysis, which reveals major physical processes causing periodic rhythms in the $\delta^{18} \mathrm{O}$ and $\delta \mathrm{D}$ ratios (e.g. regular annual cycles) (Table 2). The confidence interval for standardized spectral density of the white noise was determined according to the Kolmogorov-Smirnov criterion. The largest values of the $\delta^{18} \mathrm{O}$ periodogram relate to the high-frequency part of the spectra. The maximum variance in the $\delta^{18} \mathrm{O}$ and $\delta \mathrm{D}$ is explained by variations with a period of 30.8 in the 524 records (where 524 is the number of snow/firn-core samples from the west Belukha plateau). The period of 30.8 is associated with 17 regular annual cycles (i.e. $524 / 30.8=17$ ) in air temperature during precipitation. These cycles correspond to 17 annual accumulation layers (1984-2001) identified both in stableisotope ratios and in the snow/firn stratigraphy (Figs 5 and 6).

\subsection{Seasonal/monthly snow accumulation}

To verify the correlation between snow accumulation on the Belukha plateau $\left(\mathrm{Ac}_{\mathrm{ds}}\right)$ and precipitation at Akkem station $\left(P_{\text {Akkem }}\right)$ obtained through ice-core annual records, measurements of snow surface level at the drill site were used at daily and event scale (Fig. 8). The $F$ test demonstrated a statistically significant correlation of $r=0.72$ and 0.89 (under $n-2=31$ and 18, at $p=0.90$ ) between daily/event precipitation at Akkem station and daily/event snow accumulation at the drill site (Fig. 9). Two months of automatic daily measurements of the snow surface level did not allow development of a snow accumulation/precipitation relationship at a monthly scale. The relative value of standard error (STE in \%) of regression increases with decreasing duration of averaging: STE(year) $=104 \mathrm{~mm}$ (i.e. $14 \%$ of $690 \mathrm{~mm}$ average), STE(event) $=7.5 \mathrm{~mm}$ (i.e. $25 \%$ of $29.4 \mathrm{~mm}$ event mean) and $\operatorname{STE}($ day) $=4.5 \mathrm{~mm}$ (i.e. $37 \%$ of $12.6 \mathrm{~mm}$ daily mean). Therefore, STE(season/month) should be less than $25 \%$ (STE(event)) and more than 14\% (STE(year)).

Significant correlation $\left(\mathrm{Ac}_{\mathrm{ds}} / P_{\mathrm{Akkem}}\right)$ validated application of the normalization technique (Barlow and others, 1993; Shuman and others, 1995; Yao and others, 1999; Aizen and others, 2004) to develop the seasonal/monthly/event snow accumulation $\left(\operatorname{Ac}(\mathrm{s} / \mathrm{m} / \mathrm{e})_{\mathrm{ds}}\right)$ from snow/ice records. Annual accumulation $(\operatorname{Ac}(y))$ at the drill site was normalized by the share/fraction $(k)$ of monthly/seasonal/event precipitation in annual total $\left(P(\mathrm{y})_{\text {Akkem }}\right)$ at Akkem station (Equation (2)) (Table 3).

$$
\operatorname{Ac}(i) \mathrm{ds}=k(i) \operatorname{Ac}(\mathrm{y})
$$

where $i$ is the seasonal/monthly/event period (e.g. January, February... December), $\mathrm{Ac}(i)_{\mathrm{ds}}$ is the snow accumulation for the ' $i$ ' period of time, and $k=P_{\text {Akkem }}(i) / P(\mathrm{y})_{\text {Akkem. }}$. 

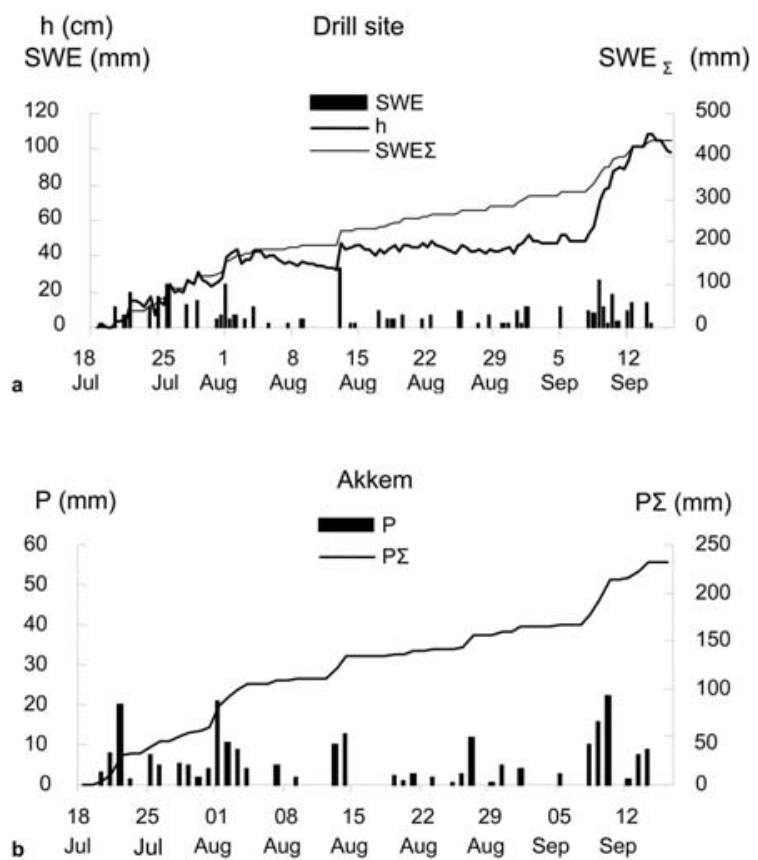

Fig. 8. Twice-daily measured snow surface level $(h)$, snow water equivalent (SWE) and accumulated snow water equivalent $\left(\mathrm{SWE}_{\Sigma}\right)$ at the drill site (a) and daily precipitation $(P)$ and accumulated precipitation $\left(P_{\Sigma}\right)(\mathrm{b})$ at Akkem meteorological station, 2001.

Monthly snow accumulation values for 2000 calculated by the normalization technique agreed with corresponding values calculated using the linear relationship of event snow surface/precipitation data (Fig. 9) and verified the developed evaluation of seasonal/monthly/event accumulation (Table 3).

Furthermore, calculated seasonal snow accumulation values were verified using the snow/firn stratigraphic profile (Fig. 6), where winter layers could be differentiated from others by their homogeneous bright-white crystal structure. In the spring layers, there are signs of 1-2 mm slender radiation crusts, while summer layers have ice lenses up to $8 \mathrm{~mm}$ thick. The autumn layers could be identified by more compact firn and yellow-brown aeolian particles. Uncertainty in calculating seasonal accumulation using the normalization technique was less than $\pm 10 \%$ of the seasonal accumulation rate obtained from the snow/firncore stratigraphic profile. Snow/firn stratigraphic profiles (Fig. 6) allowed partitioning of the firn-core layers with a seasonal resolution, while monthly precipitation data from the Akkem and Kara-Turek meteorological stations enabled profiling of the firn-core records, with monthly/event resolution for the spring, summer and autumn seasons. For example, the sulfate peak measured at $14.01 \mathrm{~m}$ is related to the firn-core layer of May-June 1991, corresponding to the
Event scale

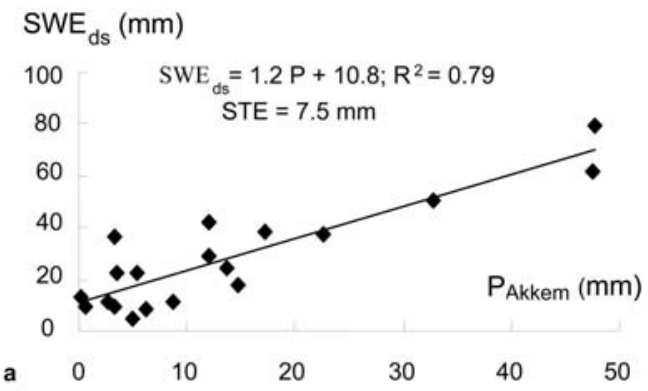

Daily scale

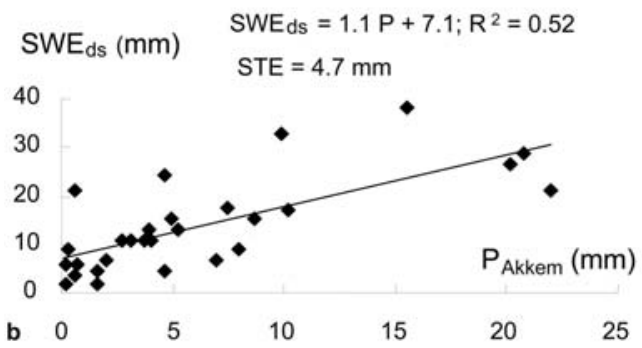

Fig. 9. (a, b) Relationships between precipitation at Akkem station $\left(P_{\text {Akkem }}\right)$ and automatically measured daily accumulation (snow water equivalent; $\mathrm{SWE}_{\mathrm{ds}}$ ) at the drill site, and between monthly precipitation at Akkem station $\left(\mathrm{P}_{\mathrm{Akkem}}\right)$ and monthly snow accumulation $\left(A c_{d s}\right)$ data obtained from ice-core records through normalization technique.

Pinatubo eruption (in June). The thin winter layers were considered as the sum of accumulation over 3 months.

The corresponding annual seasonal/monthly $\delta^{18} \mathrm{O}$ and $\delta \mathrm{D}$ compositions were averaged as arithmetic means of every $3-5 \mathrm{~cm}$ of measured stable-isotope ratios in each seasonal accumulation layer of the snow/firn core. Barlow and others (1993), Shuman and others (1995), Yao and others (1999) and Aizen and others (2004) have used the same approaches to evaluate seasonal accumulation in snow/firn/ice cores.

\subsection{Stable isotopes from firn core and snow pits}

The mean $\delta^{18} \mathrm{O}$ and $\delta \mathrm{D}$ isotope ratios from the Altai core, $-13.6 \%$ and $-98.14 \%$ respectively, are in accordance with other stable-isotope records obtained from central Asia and Siberia (Table 1). The concordance is related to the mean annual isotopic composition of precipitation from the Omsk and Eniseisk stations in southwest and southeast Siberia. However, seasonal means and deuterium excess from the station precipitation differ from the firn-core records.

Table 2. Largest periodogram values of $\delta^{18} \mathrm{O}$ and $\delta \mathrm{D}$ records in 524 snow/firn-core samples from the west Belukha plateau

\begin{tabular}{|c|c|c|c|c|c|c|c|c|c|}
\hline & & $\delta^{18} \mathrm{O}$ & & & & & $\delta \mathrm{D}$ & & \\
\hline Time series & Frequency & Period & Periodogram & Density & Time series & Frequency & Period & Periodogram & Density \\
\hline 17 & 0.032 & 30.8 & 188.37 & 102.25 & 17 & 0.032 & 30.8 & 123131.28 & 6619.54 \\
\hline 6 & 0.011 & 87.3 & 181.43 & 90.20 & 6 & 0.011 & 87.3 & 11842.30 & 5771.29 \\
\hline
\end{tabular}


Table 3. Calculation of monthly accumulation by normalization technique $\left(\mathrm{Ac}_{\mathrm{ds}}\right)$ from ice-core records and by developed equation (Fig. 9) based on snow accumulation measurements $\left(S_{W} E_{d s}\right)$ at the drill site

\begin{tabular}{lcccc}
\hline Month & $P_{\text {Akkem }}$ & $\begin{array}{c}\text { Share in } \\
P_{\Sigma}\end{array}$ & $\begin{array}{c}\mathrm{Ac}_{\mathrm{ds}} \text { by } \\
\text { normalization }\end{array}$ & $\begin{array}{c}\mathrm{SWE}_{\mathrm{ds}} \text { by equation: } \\
1.2 P_{\text {Akkem }}+10.8\end{array}$ \\
& & & $\mathrm{~mm}$ & $\mathrm{~mm}$ \\
\hline Dec & 17.2 & 0.03 & 23.2 & 31.4 \\
Nov & 13.4 & 0.02 & 18.1 & 26.9 \\
Oct & 34.8 & 0.06 & 47.0 & 52.6 \\
Sept & 35.2 & 0.06 & 47.5 & 53.0 \\
Aug & 96.9 & 0.17 & 130.9 & 127.1 \\
Jul & 70.8 & 0.12 & 95.6 & 95.7 \\
Jun & 132.2 & 0.23 & 178.5 & 169.4 \\
May & 94.8 & 0.17 & 128.0 & 124.6 \\
Apr & 49.7 & 0.09 & 67.1 & 70.4 \\
Mar & 11.6 & 0.02 & 15.7 & 24.7 \\
Feb & 6.5 & 0.01 & 8.8 & 18.6 \\
Jan & 4.8 & 0.01 & 6.5 & 16.6 \\
$P_{\Sigma}$ & 567.9 & 1 & $\mathrm{STE}=0.036 \mathrm{~mm}(0.06 \%)$ \\
\hline
\end{tabular}

Note: $P_{\text {Akkem }}$ is monthly precipitation at Akkem station; $P_{\Sigma}$ is share of monthly precipitation in annual total.

The higher average annual as well as cold-season air temperatures at the Altai drill site correspond to higher mean annual and cold-season oxygen isotope ratios showing slightly less depletion of the heavy isotopes than measured in the Inilchek glacier core, in the Tien Shan (Table 1). The higher minimum $\delta^{18} \mathrm{O}$ values in the Altai snow/firn core than from the Tien Shan winter records are caused by shorter trajectories of air masses bringing moisture to the Altai glaciers from the same moisture source, demonstrating the continental effect depleting the meteoric water moving farther from the source of water vapor (Dansgaard, 1964; Friedman and others, 1964). During the cold season, the airmass influxes move over the Eurasian continent, eastward along the main route: from the high latitudes of Iceland to western Siberia and then to central Asia (Glukh and
Kononova, 1982). Furthermore, proportionally less coldseason, i.e. October-April, precipitation amounts at the Altai drill site compared to the Tien Shan result in a higher mean isotope ratio in the Belukha plateau firn-core records (Table 4). For example, $17 \%$ of cold-season precipitation at the Altai drill site, with $-15.3 \%$ of $\delta^{18} \mathrm{O}$ mean during the cold season, resulted in a $1.7 \%$ depletion of the annual mean level, while $28 \%$ of cold-season precipitation at the Tien Shan, with $-21.78 \%$ of $\delta^{18} \mathrm{O}$ mean, resulted in a $5.74 \%$ depletion of the annual mean level.

Mean $\delta^{18} \mathrm{O}$ isotope values of the annual records show similar averages throughout the period 1984-2001, varying from $-15.5 \%$ to $-12.3 \%$. The distribution in $\delta^{18} \mathrm{O}$ and $\delta \mathrm{D}$ records from the Altai snow/firn core shows well-preserved seasonal variations (Fig. 5) and is significantly controlled by temperature (Table 1 ), by share of cold/warm-season precipitation amount and by precipitation origin (Appendix; Fig. 10). The share of cold/warm season, i.e. October-April precipitation/May-September precipitation, was determined as the fraction of monthly total precipitation amount (Fig. 4a) in the annual total. Mean monthly oxygen isotope ratios from the Altai snow/firn core reflected a typical continental climate with an overall range between absolute maximum and minimum values of $16.6 \%$, corresponding to the amplitude of maximum and minimum air temperatures observed from 1984 to $2001\left(\Delta T=31^{\circ} \mathrm{C}\right)$ (Table 1).

The highest monthly mean $\delta^{18} \mathrm{O}$ values of $-13.4 \%$ are related to the warm-season accumulation layers, with mean air temperatures of $-1.8^{\circ} \mathrm{C}$ (Table 1 ). Cold season minimum mean $\delta^{18} \mathrm{O}$ values of $-15.3 \%$ were associated mainly with minimum mean air temperatures of $-14.8^{\circ} \mathrm{C}$. The highest variability in seasonal $\delta^{18} \mathrm{O}$ and $\delta \mathrm{D}$ was observed in the cold-season firn layers, whereas the most variable season for air temperatures is from the end of autumn to the beginning of spring (Fig. 4a and b).

\subsection{Relationship between stable hydrogen- and oxygen-isotope ratios}

The slope and intercept in the covariance between the stable hydrogen and oxygen isotopic concentration found in most meteoric water and defined by Craig (1961) as the global

Table 4. Clustered average/extreme $\delta^{18} \mathrm{O}$ and $\mathrm{d}$-excess values from accumulation layers formed by precipitation originating from central Asian (CA) and oceanic moisture sources, their share (\%) in the total annual and seasonal accumulation layers and uncertainty (\%) of clustering

\begin{tabular}{|c|c|c|c|c|c|c|c|c|c|c|c|c|c|}
\hline \multirow[b]{2}{*}{ SP } & \multirow[b]{2}{*}{ Moisture source } & \multirow[b]{2}{*}{ Max. } & \multirow{2}{*}{$\begin{array}{l}\delta^{18} \mathrm{O} \\
\text { Min. }\end{array}$} & \multicolumn{4}{|c|}{ d-excess } & \multicolumn{5}{|c|}{$\begin{array}{c}\text { Share } \\
\text { Uncertainty }\end{array}$} & \multirow[t]{2}{*}{ Seasons } \\
\hline & & & & $\begin{array}{l}\text { Ave. } \\
\text { Mean a }\end{array}$ & $\begin{array}{l}\text { Max. } \\
\text { Total acc } \\
\text { cumulati }\end{array}$ & $\begin{array}{l}\text { Min. } \\
\text { mulatior } \\
\text { rate }(m\end{array}$ & $\begin{array}{l}\text { Ave. } \\
\text { nmw.e.) } \\
\text { w.e. } \mathrm{a}^{-1} \text { ) }\end{array}$ & $\begin{array}{c}\text { Year } \\
12591 \\
690\end{array}$ & $\begin{array}{c}\text { Spr. } \\
3037 \\
133\end{array}$ & $\begin{array}{c}\text { Summ. } \\
6752 \\
376\end{array}$ & $\begin{array}{c}\text { Aut. } \\
1967 \\
129\end{array}$ & $\begin{array}{c}\text { Wint. } \\
834 \\
52\end{array}$ & \\
\hline & Oceanic & -8.1 & -19.7 & -13.3 & 12.0 & 1.1 & 8.1 & $\begin{array}{l}67 \\
\pm 7\end{array}$ & $\begin{array}{l}67 \\
\pm 9\end{array}$ & $\begin{array}{l}68 \\
\pm 5\end{array}$ & $\begin{array}{l}60 \\
\pm 6\end{array}$ & $\begin{array}{l}76 \\
\pm 19\end{array}$ & Year \\
\hline WC & Atlantic & -9.7 & -19.7 & -13.8 & 12.0 & 7.0 & 9.6 & $\begin{array}{l}56 \\
\pm 6\end{array}$ & $\begin{array}{l}57 \\
\pm 7\end{array}$ & $\begin{array}{l}60 \\
\pm 4\end{array}$ & $\begin{array}{l}36 \\
\pm 4\end{array}$ & $\begin{array}{c}76 \\
\pm 19\end{array}$ & Spr., aut. \\
\hline UP, NWC & Arctic/ & -8.1 & -16.7 & -12.4 & 7.8 & 1.1 & 5.6 & $\begin{array}{l}11 \\
\pm 8\end{array}$ & $\begin{array}{l}10 \\
\pm 8\end{array}$ & $\begin{array}{c}8 \\
\pm 7\end{array}$ & $\begin{array}{l}24 \\
\pm 9\end{array}$ & & Summ. \\
\hline StCyc & Pacific & & & & & & & $\begin{array}{l}10 \\
\pm 7\end{array}$ & $\begin{array}{c}10 \\
\pm 14\end{array}$ & $\begin{array}{c}9 \\
\pm 7\end{array}$ & $\begin{array}{c}7 \\
\pm 6\end{array}$ & & Summ. \\
\hline
\end{tabular}

Note: SP is prevailing synoptic pattern; SWC is southwestern cyclone; WC is western cyclone; UP is ultra-polar intrusion; StCyc is stationary cyclone; Spr., Summ., Aut., Wint. are spring, summer, autumn, winter. 


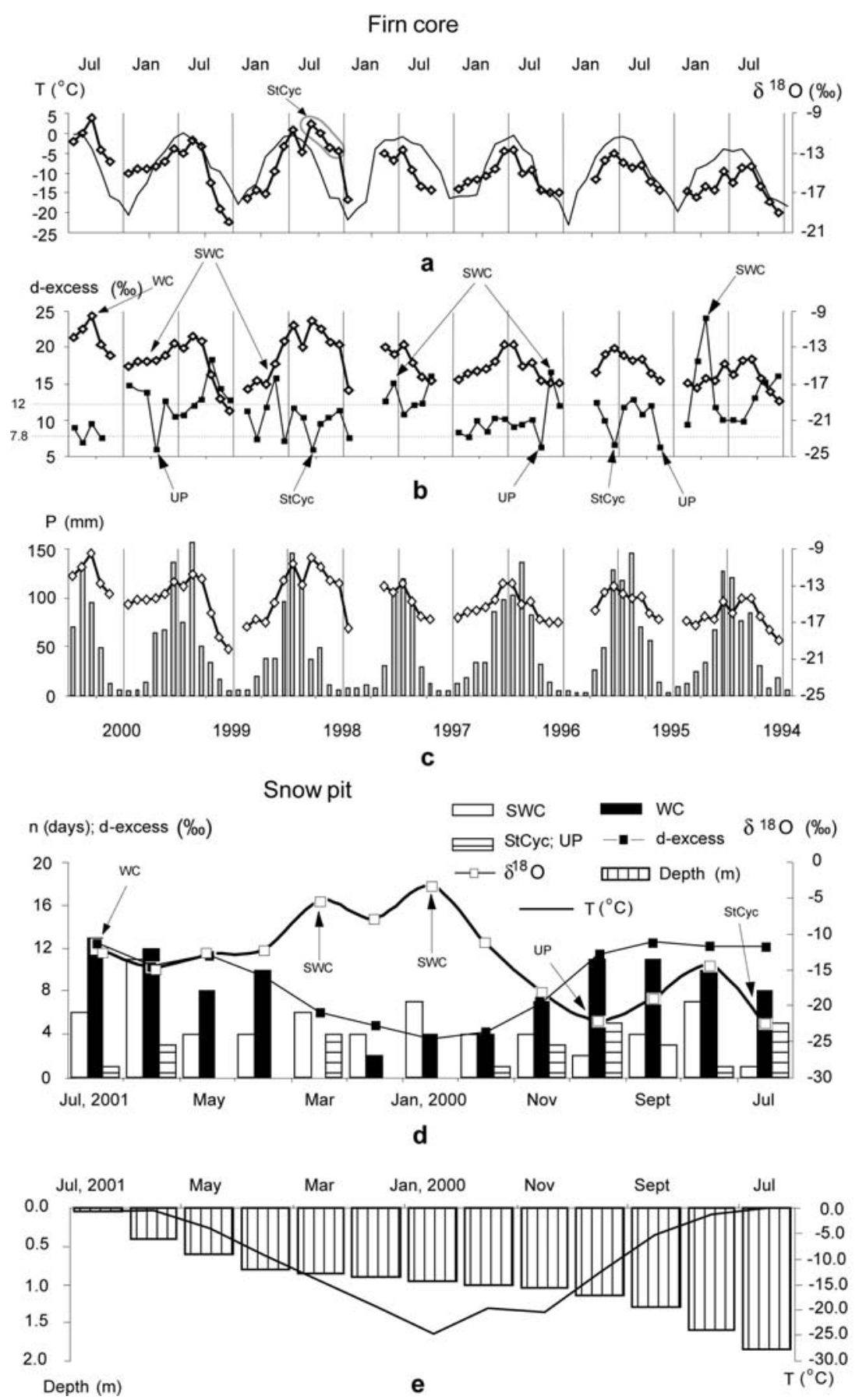

Fig. 10. (a-c) Monthly means of $\delta^{18} \mathrm{O}$ averaged from Altai snow/firn-core records and air temperature at the drill site (a) and d-excess (b), and precipitation amount at Akkem station (c). (d) Monthly means of $\delta^{18} \mathrm{O}$ and d-excess records obtained from snow pit, 2000/01, and number of days with synoptic patterns, $n$, that brought precipitation to the Altai. (e) Mean monthly air temperature at the drill site and snow accumulation measured from snow pit, 2000/01.

meteoric water line $(\mathrm{GMWL})$ are useful in understanding the systematics of isotopic fractionation (Kendall and McDonnell, 1998). The slope of the GMWL, 8, is related to the ratios of fractionation factors, when the minor dissimilarity is caused by a kinetic fractionation effect during evaporation. The intercept of the GMWL, 10, is termed the deuterium excess (d-excess), a concept introduced by Dansgaard (1964), i.e. d-excess $(\%)=\delta \mathrm{D}-8 \delta^{18} \mathrm{O}$. Deuterium excess is a parameter reflecting re-evaporation at land surfaces and/ or mixing along air-mass trajectories. A smaller or larger intercept in the local relationship, from the snow/firn core, fresh snow, snow pit and precipitation, compared with the
GMWL (Fig. 11a) reflects different kinetic evaporation effects on the transferred water vapor (e.g. initial water vapor was more quickly or slowly evaporated under non-equilibrium conditions (Kendall and McDonnell, 1998)). The amount of d-excess is dependent on sea surface temperatures during evaporation, as well as other physical conditions including fractioning of isotopes during ice crystal formation in clouds, re-evaporation/sublimation of snow below clouds in unsaturated air, and post-depositional modification of the isotope signal, for example by melting, evaporation, sublimation and wind erosion (Merlivat and Jouzel, 1979; Jouzel and Merlivat, 1984; Ciais and Jouzel, 1994). 
a

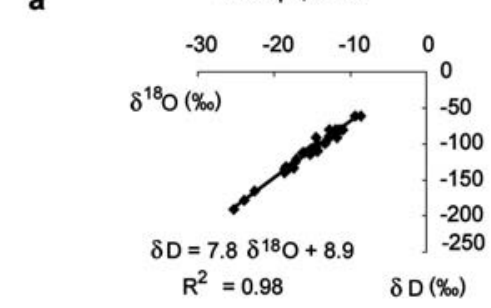

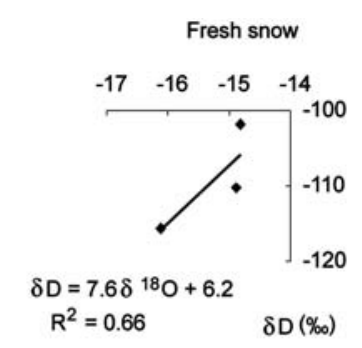
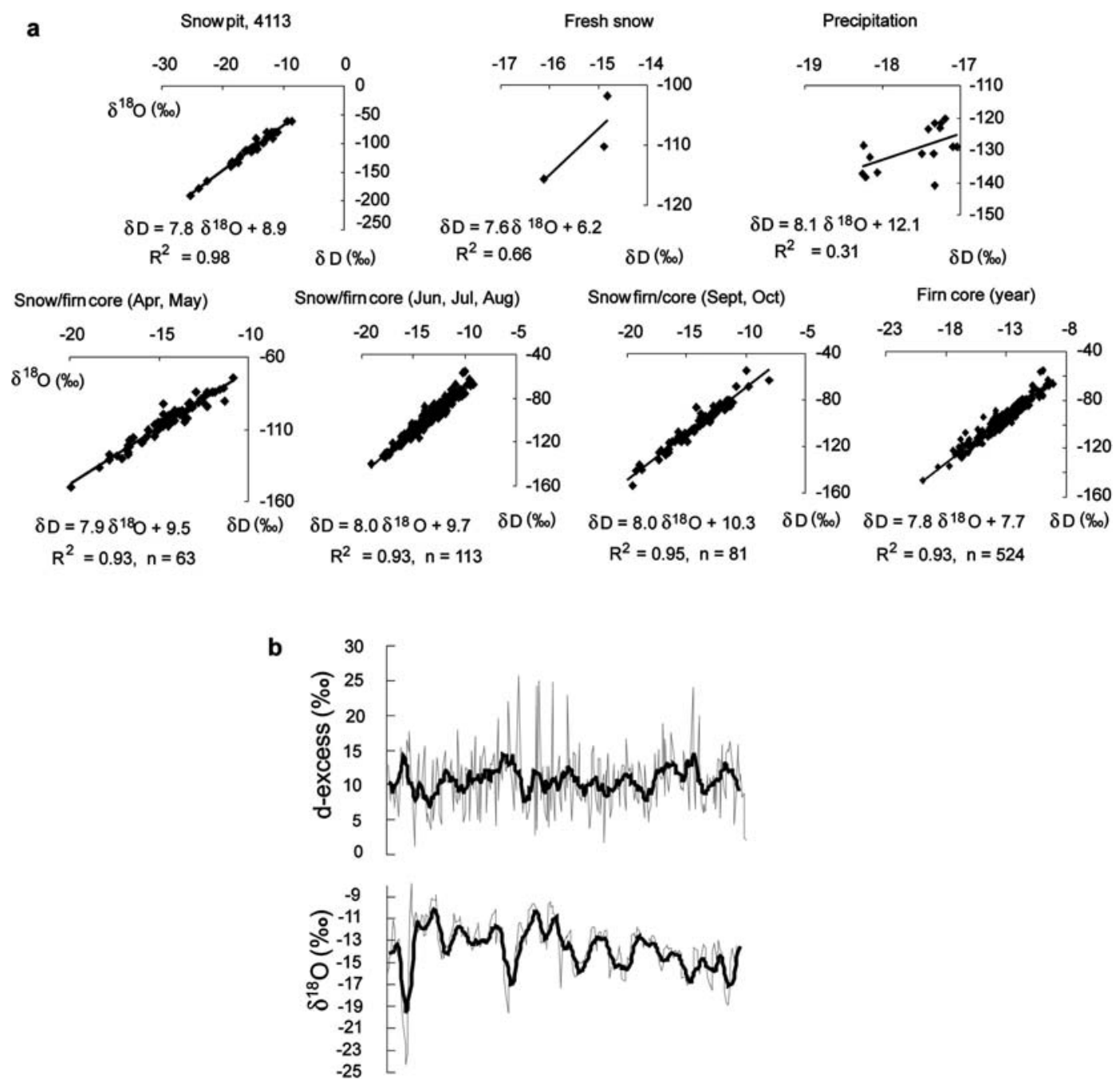

Fig. 11. (a) Annual and seasonal deuterium $(\delta \mathrm{D})$ and oxygen $\left(\delta^{18} \mathrm{O}\right)$ isotope relationship (Altai $\left.M W L\right)$ in snow pit, fresh snow, precipitation and snow/firn core on the west Belukha plateau, 2001. (b) Distribution of d-excess and $\delta^{18} \mathrm{O}$ and ten-sample averages from Altai 2001 snow/ firn core.

The $\delta{ }^{18} \mathrm{O}-\delta \mathrm{D}$ relationship in the precipitation, snow pits and snow/firn core from the Belukha plateau (Fig. 11a) has a similar slope to the covariance (i.e. 8) as that of the GMWL, indicating the same initial relationship of fractionation factors, and points to the absence of strong melt and percolation in the snow/firn core. The slopes did not approach typical sublimation/evaporation line slopes of about 5 (Clark and Fritz, 1997).

The spatial distribution of the long-term annual averages of d-excess in snow/firn-core records and precipitation is characterized by a significant spread, ranging from $23 \%$ for the Tien Shan firn-core records to $4.1 \%$ from precipitation at Irkutsk station in eastern Siberia (Table 1). Another eastern Siberian station, Eniseisk, also demonstrated a relatively low d-excess value of $7.9 \%$. At the western Siberian stations, Omsk and Novosibirsk, long-term annual averages of $d$-excess gradually increase to $8.9 \%$ and $12.8 \%$ respectively.

The average $d$-excess of snow/firn-core records varies around $10.9 \%$, similar to the intercept of the GMWL. There is a correlation between the two isotope parameters $\left(r^{2}=0.93\right)$ and close accordance between the Altai meteoric water line (MWL) and GMWL (Fig. 11a). The $\mathrm{d}$-excess variability is preserved throughout the core record, ranging from $1.8 \%$ o to $29.7 \%$. The d-excess values vary from $8 \%$ to $14 \%$ in $>50 \%$ of snow/firn-core records (Fig. 12 ).

Along with the significant influence of snow formation temperature on d-excess, we assume that in the alpine areas of central Asia the large (up to 18\% in 1994/95; Figs 4b and $10 \mathrm{~b}$ and $\mathrm{d}$ ) seasonal fluctuations in Altai d-excess values (Hoffmann and others, 1998; Holdsworth and Krouse, 2002; Kreutz and others, 2003) are explained by regional-scale hydrological processes such as source, transport and recycling of atmospheric moisture. Low air temperatures during cold dry seasons and high humidity during warm seasons, when the main precipitation occurs (83\% (Fig. 4a; Table 1)), reduces the effect of partial re-evaporation of snowflakes below clouds and of sublimation from snow surfaces on the firn-core records. Post-depositional effects of melt/refreezing and evaporation/sublimation from the surface on the west Belukha plateau are negligible because positive temperatures were never observed at the drill site which is located in the cold recrystallization zone (Fig. 3a and $b)$.

The long-term monthly means of d-excess show welldefined and systematic seasonal variations (Figs $4 \mathrm{~b}$ and 10d), with a mean maximum in February/January and a minimum in August/July. A firn/ice core drilled in the 


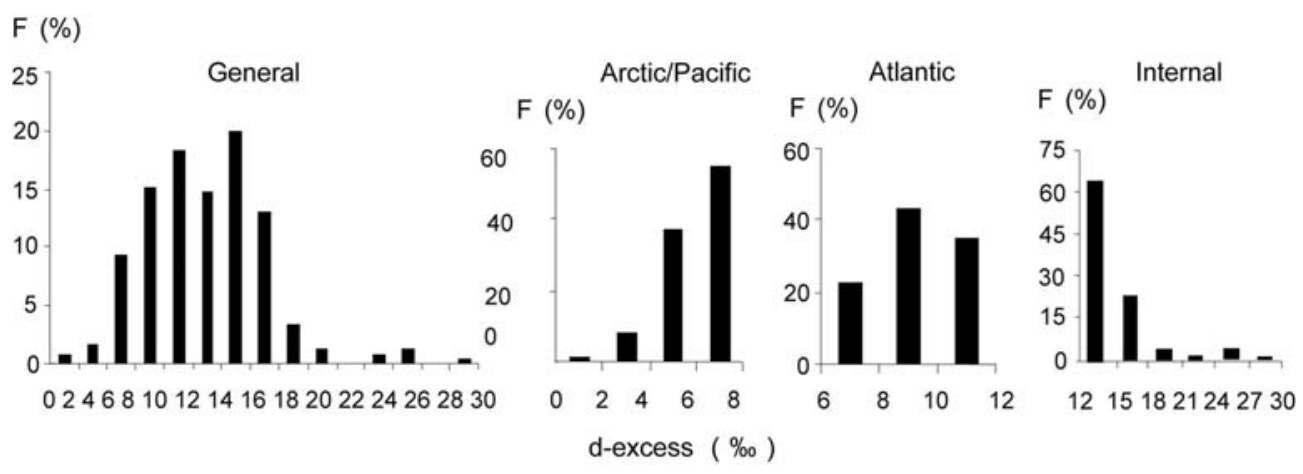

Fig. 12. Probability distribution of $d$-excess values $(F$ in \%) in snow/firn-core records from precipitation originating over different moisture sources.

Tien Shan (Kreutz and others, 2003) exhibits seasonal $\mathrm{d}$-excess and $\delta^{18} \mathrm{O}$ variability similar to that in the Altai, i.e. lowest $\mathrm{d}$-excess and highest $\delta^{18} \mathrm{O}$ values correspond to the summer season with maximum precipitation and air temperatures. On the other hand, a firn core from Tsast Ula ice cap, Mongolia, displays inverted seasonal levels of $\mathrm{d}$-excess and $\delta^{18} \mathrm{O}$ (Schotterer and others, 1996).

From May to January, the long-term monthly means of d-excess are almost constant, 9.5-11.2\%o (Fig. 4b), with about the same intercept as for the GMWL. From February to April, d-excess increased and reflects the modification of air masses during passage over relatively warm continental waters (Gat and Dansgaard, 1972; Gat and Carmi, 1987).

Compared to the Northern Hemisphere stations, where the average $d$-excess values reach a maximum in December/ January and a minimum in June/July (Froehlich and others, 2002), Altai snow/firn-core records show a delay of about 1 month (Fig. 4b). This insignificant asymmetry probably reflects the interior and elevated location of the Altai drill site, and complexly originated precipitation inputs to the west Belukha accumulation areas. The long-term mean extremes in the seasonal variation of d-excess values from the Altai snow/firn-core record range from 15.5\% to 9.5\% (Fig. 4b), insignificantly higher than corresponding values from Northern Hemisphere stations, which varied from $12.1 \%$ to $7.7 \%$ (Froehlich and others, 2002). Low snowformation temperatures partially caused increasing d-excess values in the firn-core records (Ciais and others, 1995).

At the end of winter/beginning of spring, warming occurs faster in the inner-continental regions than in the coastal regions, increasing inland evaporation. Low-humidity conditions in the cold-season continental air masses cause rapid evaporation, and hence high d-excess values in subsequent precipitation. Long-range transport of air masses from the eastern Black Sea, Caspian and Aral Seas causes conditions favorable to rapid evaporation and the formation of high $\mathrm{d}$-excess values in the insignificant precipitation that accumulates on the Altai glaciers during these months (Fig. 4a and b).

During the warm season, moisture is brought by western and northwestern air masses formed under relatively high air temperatures and humidity conditions that are associated with low d-excess values.

\subsection{Synoptic patterns and precipitation origin}

To identify the origin and trajectories of moisture, the mean seasonal amount of precipitation, $\delta^{18} \mathrm{O}$ isotopic content and d-excess values in the snow firn-core records were compared with the monthly frequency of synoptic patterns using correlation analysis.

The main synoptic pattern that brings moisture to the Siberian Altai during the year is the western cyclones $\left(W_{a, b}\right)$ and western anticyclones $\left(W_{a}\right)$ (Appendix), which have a high correlation with monthly precipitation amount (Table 5) and a significant number of events (Fig. 4c-e). The frequency of $W C_{b}$ and $W A_{c}$ is positively associated with $\delta^{18} \mathrm{O}$ isotopic content in related firn-core accumulation layers.

Air masses originating over the Arctic Ocean bring precipitation to the Siberian Altai by northwestern cyclones (NWC) in spring, by ultra-polar influxes (UP) in autumn, and partially by $W_{c}$ in the summer. Strong depletion in $\delta^{18} \mathrm{O}$ and in d-excess records associated with these synoptic patterns (Table 5) points to the rain-out effect of water vapor (Rayleigh distillation model) and is in agreement with results presented by Froehlich and others (2002). Mixing with water vapor evaporated from more northern oceanic areas may account for the observed slight depletion of $d$-excess values.

Summer precipitation is significantly associated with the frequency of stationary cyclones (Table 5), which increase the level of $\delta^{18} \mathrm{O}$ enrichment and d-excess depletion in firncore accumulation layers. Stationary cyclones bring precipitation to the Altai that originates from the Pacific Ocean. This result is in agreement with estimations based on aerological observations (Kuznezova, 1984) that the mean summer horizontal moisture transport over the Altai has a strong eastern component.

There is a positive correlation between the frequency of southwestern cyclones and spring/winter amount of precipitation and d-excess values. These results are in agreement with the nature of the synoptic processes (see Appendix). Moisture in the southwestern cyclones originates over the eastern Black Sea, the Caspian and Aral Seas and is transferred to the Altai at low altitudes and from low latitudes, precipitating with exceptionally high d-excess values. According to Froehlich and others (2002), exceptionally high $d$-excess values were recorded at stations receiving precipitation from the eastern Mediterranean Sea. A negative correlation coefficient between the southwestern-cyclone frequency pattern and $\delta^{18} \mathrm{O}$ is a result of reevaporating water vapor from the southern internal moisture sources in winter, which moves northward over the cold Asian continent, mixing with cool air masses, and accounts for strong $\delta^{18} \mathrm{O}$ depletion. 
Table 5. Correlation (at $10 \%$ ) between seasonal frequency of synoptic patterns (SP) observed over western Siberia and the amount of precipitation at Akkem station $\left(P_{\text {Akkem }}\right)$ based on data for 1954-2001; annual association (at 20\%) between monthly mean SP and monthly mean of $\delta^{18} \mathrm{O}$ concentration and d-excess in snow/firn core obtained from the west Belukha plateau

\begin{tabular}{|c|c|c|c|c|c|c|c|c|}
\hline & NWC & UP & $W C_{a}$ & $W C_{b}$ & $W_{a}$ & $\mathrm{WA}_{\mathrm{c}}$ & StCyc & SWC \\
\hline Origin of SP & Arctic & Arctic & Atlantic & Atlantic & $\begin{array}{c}\text { Arctic/ } \\
\text { N. Atlantic }\end{array}$ & $\begin{array}{c}\text { Arctic/ } \\
\text { N. Atlantic }\end{array}$ & Pacific & Central Asia \\
\hline \multicolumn{9}{|l|}{$P_{\text {Akkem }} / \mathrm{SP}$} \\
\hline Summer & 0.34 & & 0.42 & & 0.34 & 0.36 & & \\
\hline Spring & 0.45 & & 0.37 & 0.67 & & & & 0.36 \\
\hline Autumn & & 0.32 & 0.36 & 0.3 & 0.36 & & 0.28 & \\
\hline Winter & & & & 0.85 & 0.38 & & & 0.42 \\
\hline Year & 0.31 & 0.39 & 0.34 & 0.56 & 0.33 & 0.31 & 0.44 & 0.31 \\
\hline \multicolumn{9}{|l|}{$\delta^{18} \mathrm{O} / \mathrm{SP}$} \\
\hline Year & & -0.69 & 0.64 & 0.64 & 0.31 & 0.53 & 0.62 & \\
\hline \multicolumn{9}{|l|}{ d-excess/SP } \\
\hline Year & -0.51 & -0.49 & -0.33 & -0.5 & -0.29 & -0.62 & -0.53 & 0.39 \\
\hline
\end{tabular}

Note: NWC is northwestern cyclone; UP is ultra-polar intrusion; $W_{\mathrm{a}}$ and $\mathrm{WC}_{\mathrm{b}}$ are western cyclones; $\mathrm{WA}_{\mathrm{a}}$ and $\mathrm{WA}_{\mathrm{c}}$ are western anticyclones; StCyc is stationary cyclone; and SWC is southwestern cyclone.

\section{DISCUSSION}

\subsection{Clustering precipitation transferred from external (oceanic) and internal (continental) moisture sources}

Stable-isotope distribution in the snow/firn core (see section 5.4) and the synoptic regime (see section 5.5), examined from the Siberian Altai, shows evidence of multiple moisture sources. In order to distinguish the sources of precipitated moisture, the $K$-means clustering and regression analyses were applied.

\subsubsection{K-means clustering analysis}

To distinguish oceanic moisture from water vapor evaporated from internal drainage basins and transferred to the high/middle latitudes of Asia, the $\delta^{18} \mathrm{O}$ isotopic ratio and $\mathrm{d}$-excess values from the Altai snow/firn core were clustered into two distinct datasets. The clustering procedure was based on the $K$-means clustering analysis method of splitting a dataset into two groups by maximizing between-cluster variation relative to within-cluster variation. The first cluster is typified by the more depleted $\delta^{18} \mathrm{O}$ values (down to $-24.7 \%$ ) and d-excess values higher than $12 \%$, with an average value of $14.7 \%$ and maxima reaching $25.6 \%$ (Table 4). The d-excess values in the other cluster are lower than $12 \%$, with an average value of $8.1 \%$ and an absolute minimum of $1.1 \%$. The $\delta^{18} \mathrm{O}$ mean and maximum values are slightly more enriched than in records related to the first clusters.

\subsubsection{Calibration of precipitation events}

To evaluate the link between stable-isotope concentrations in the firn-core profile and atmospheric circulation dynamics, we matched the measured $\delta^{18} \mathrm{O}$ concentration and $d$-excess values in snow-pit layers to corresponding precipitation events observed at the Akkem meteorological station from July 2001 to July 2000. These snow accumulation event values were calculated using a normalization technique (Equation (2)) which was verified through the linear relationship obtained from snow accumulation measurements (Equation (1)) (see Fig. 9). The $\delta^{18} \mathrm{O}$ concentration and $\mathrm{d}$-excess mean in snow layers during precipitation events were related to the synoptic patterns (see Appendix) of associated precipitation (Fig. 13). Analysis of synoptic processes prevailing during precipitation events over western Siberia and the Altai is in accordance with results from the $K$-means clustering with $\pm 7.4 \%$ or about $15 \%$ of deviation (i.e. amount of accumulation, $929 \mathrm{~mm}$, in total accumulation, $12591 \mathrm{~mm}$, where the stable-isotope distribution was not in accordance with developed clustering). Greater uncertainty occurred during winter months, when several insignificant precipitation events with both internal and external moisture sources were associated with the same snow accumulation layer (Table 4).

The records with the highest deuterium excess (d-excess $\geq 12 \%$ ) are associated with precipitation occurring during southwestern cyclones, bringing internal moisture. The records with the lowest deuterium excess (d-excess $<12 \%$ ) are associated with synoptic processes bringing moisture that originates from external (oceanic) moisture sources. The snow/firn-core records with external moisture sources ( $d$-excess $<12 \%$ ) were further verified by examining the observed synoptic processes during precipitation events of 2000/01 (Fig. 13). Atlantic moisture sources are associated with slightly higher d-excess, ranging from $7.0 \%$ to $12 \%$. Moisture of Arctic and Pacific origin is associated with the lowest d-excess levels $(<7.8 \%$ ) (Table 4$)$.

\subsubsection{Verification at a monthly average scale}

\subsubsection{Snow-pit records}

Monthly average $\mathrm{d}$-excess and $\delta^{18} \mathrm{O}$ values in snow-pit layers (Fig. 10d and e), together with the corresponding monthly frequency of synoptic patterns, verified the developed clustering of precipitation origin (Table 4):

1. Southwestern cyclones were the prevailing synoptic pattern from January to March 2001, when d-excess was higher at $12 \%$ and continental, low-humidity air masses brought insignificant amounts of recycled precipitation, with depleted $\delta^{18} \mathrm{O}$ values, to the Altai from internal moisture sources. In the cold season of 2001, southwestern cyclones caused a growth of monthly d-excess means that reached $16 \%$ (Fig. 10d). 


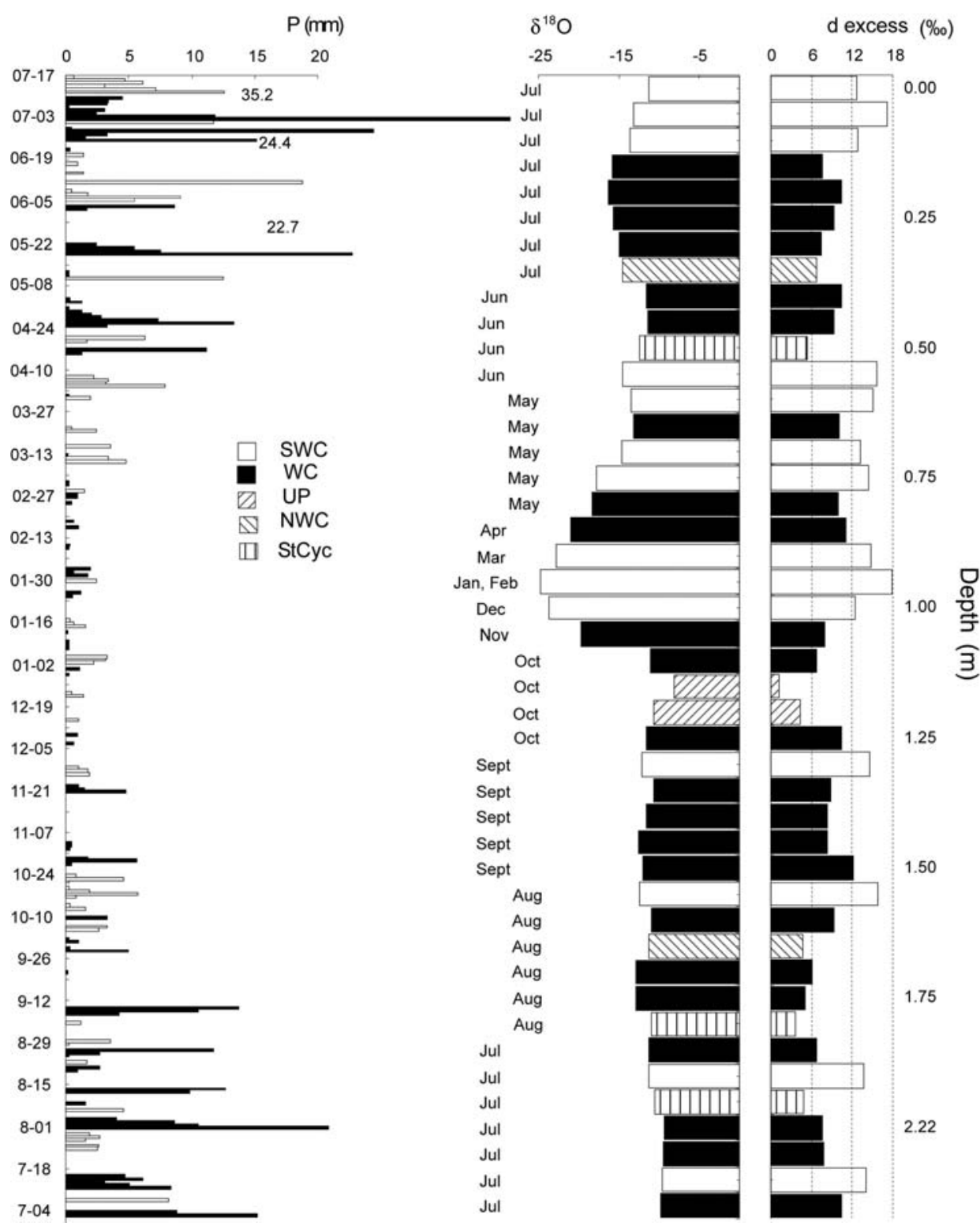

Fig. 13. (a) Verification of $d$-excess and $\delta^{18} \mathrm{O}$ clustering at the event timescale through precipitation occurring during the observed synoptic pattern at the meteorological station. (b, c) Corresponding snow-pit isotope records.

2. Annual monthly frequency of ultra-polar influxes reached a maximum (up to 6 days) in October, resulting in depleted d-excess monthly values (down to 5\%) despite an intensive development of western cyclones. Ultra-polar influxes are associated with Arctic or North Atlantic Ocean moisture origin.

3. In July 2000, intensive development of stationary cyclones (up to 5 days) brought moisture from the east, causing depletion in d-excess values (down to $5 \%$ ).

4. Monthly d-excess means ranged from $7 \%$ o to $12 \%$ during the remaining months, with the main precipitation associated with western cyclones bringing moisture from the Atlantic Ocean.

\subsubsection{Snow/firn-core records}

The monthly $\delta^{18} \mathrm{O}$ and d-excess means from firn-core records were compared to the instrumental air-temperature and precipitation monthly means at the drill site (Fig. 10a-C). Observed interannual $\delta^{18} \mathrm{O}$ fluctuations that cannot be accounted for by air-temperature fluctuations were explained by increased monthly frequency of synoptic patterns. For example, an abnormally enriched $\delta^{18} \mathrm{O}$ mean of $-10 \%$ from the accumulation layer of May 1998 (falling above the long-term May average of $-13 \%$; Fig. 4b) coincides with an abnormally depleted d-excess monthly mean of $6.9 \%$ (falling above the long-term average of $11 \%$ ) and is inconsistent with the May mean air temperature (Fig. 10a). Abnormally frequent development of stationary-cyclone synoptic patterns, which brought moisture from the east (e.g. Pacific Ocean), were observed at the end of spring, reaching 6 days in May (falling above the long-term average of 0.4 days in May (Fig. 4e)) and caused a disparity between the monthly levels of $\delta^{18} \mathrm{O}$ and air temperature. The uncertainty in developed clustering, which was validated by analyzing deviations in monthly means of $\delta^{18} \mathrm{O}$, d-excess, air temperature, precipitation and synoptic pattern frequency (Fig. 10a-C), was at $\pm 4 \%$ (Atlantic cluster in summer and autumn), reaching $\pm 21 \%$ during the winter months. 


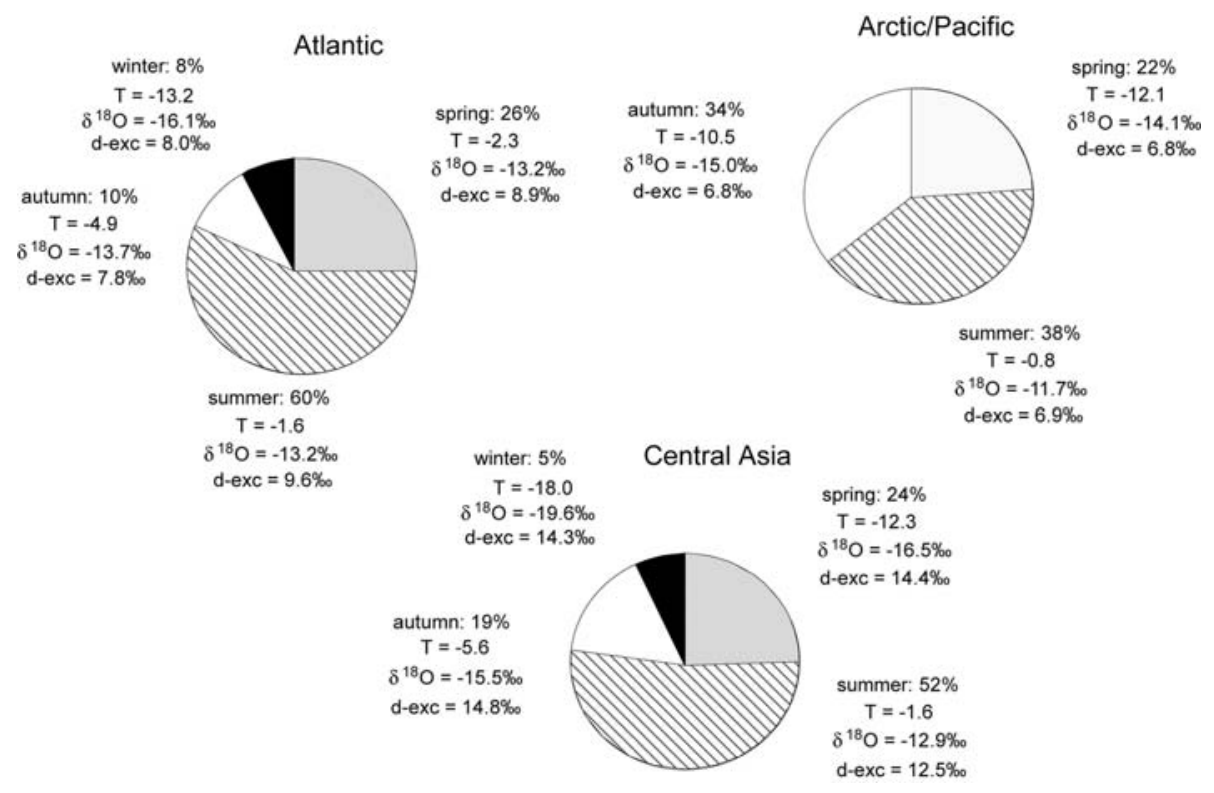

Fig. 14. Annual and seasonal contributions to accumulation of precipitation originating from external and internal moisture sources: percentage of average oxygen, deuterium and deuterium excess.

\subsection{Contribution of precipitation transferred from external and internal moisture sources to Altai accumulation}

Total snow/firn accumulation in the Altai core from June 1984 to July 2001 amounted to $12591 \mathrm{~mm}$ w.e. Of this total, $67 \%$ corresponds to precipitation transferred by western, northwestern and stationary cyclones, western anticyclones, and ultra-polar intrusions from oceanic moisture sources (Table 4). Precipitation over the Siberian Altai is mainly marine in origin during all seasons, with the oceanic share quite steady, ranging from $76 \%$ in winter to $60 \%$ in autumn accumulation. Moisture associated with synoptic patterns corresponding to water vapor evaporated over the Atlantic Ocean comprises $56 \%$ of annual accumulation. Precipitation transferred from an external moisture source, with the lowest d-excess levels, comprises on average $11 \%$ of annual accumulation, with an autumn maximum (up to $24 \%$ ) and a summer minimum (8\%) (Table 4$)$.

The remaining $34 \%$ of annual precipitation is transferred by southwest cyclones from internal moisture sources, with the largest share, $40 \%$, occurring in autumn (Table 4). The smallest share of recycled precipitation (24\%) transferred from internal moisture sources to the Altai glaciers was observed in winter, when the Siberian high is strongest over northern and central Asia, blocking the intrusion of air masses, and conditions for inland evaporation and local convection are weakest because of low continental heating.

Summer is the main season for accumulation, from both external and internal moisture sources (Fig. 14). There are no records with low d-excess values (Arctic Ocean) in accumulation layers related to winter months, while Atlantic moisture as well as recycled moisture over central Asia was brought to the Siberian Altai year-round. From autumn to spring, $\delta^{18} \mathrm{O}$ records associated with inter-land moisture sources are more depleted than $\delta^{18} \mathrm{O}$ records related to Atlantic moisture sources (Fig. 14) because of lower air temperatures over the continent than over the ocean. Summer mean isotope records are almost the same. The mean values of $\delta^{18} \mathrm{O}$ from summer accumulation layers, with Arctic/Pacific precipitation sources, are the most enriched of the three clusters considered, reaching $-11.7 \%$. The highest $\delta^{18} \mathrm{O}$ values may be associated with the highest air temperature during precipitation and/or nearby water-vapor formation (e.g. Arctic/Pacific Ocean or local summer convection).

\section{CONCLUSION}

The west Belukha snow/firn plateau is in the cold recrystallization zone where positive temperatures were never observed at the drill site. The post-depositional effect of melt/refreezing and evaporation/sublimation from the surface on the west Belukha plateau is negligible, and we found no sign of water percolation.

A clear seasonal signal in $\delta^{18} \mathrm{O}$ and $\delta \mathrm{D}$ isotopes was the basis for identification of annual accumulation layers, along with stratigraphic analysis. Validation of the dating through the marker horizon of the Pinatubo volcanic eruption showed monthly correspondence. The mean accumulation rate of $690 \mathrm{~mm}$ w.e. $\mathrm{a}^{-1}$ agrees with the annual accumulation rate validated through tritium and ${ }^{210} \mathrm{~Pb}$ records by Olivier and others (2003) and snow accumulation measured by snow stakes during 3 years.

The distribution of isotope records and d-excess values shows well-preserved seasonal variations, which are significantly controlled by temperature, cold- or warm-season precipitation amount, and precipitation origin.

The $\delta^{18} \mathrm{O}-\delta \mathrm{D}$ relationship in the Altai snow/firn-core records has the same slope to the covariance as that of the GMWL, indicating the same initial relationship of fractionation factors, and points to the absence of melt/percolation in the firn core. The average d-excess of firn-core records varies around $10.9 \%$, about the same as the intercept in the covariance of the GMWL.

The technique of coupling synoptic climatology and meteorological data with $\delta^{18} \mathrm{O}$ and d-excess firn-core records was developed to determine climate-related signals and to identify the origin of moisture. The firn-core records 
were calibrated at event-scale level and validated using the monthly meteorological data.

Clustering analysis of 17 year snow/firn-core isotope records and examination of synoptic atmospheric patterns show that two-thirds of the annual accumulation is formed from oceanic precipitation; the rest of the precipitation is recycled over Aral-Caspian sources. More than half of the accumulation has an Atlantic Ocean origin, and precipitation from the Arctic and Pacific Oceans contributes on average $11 \%$ to the annual accumulation.

On an annual basis, the main synoptic pattern that brings moisture to the Siberian Altai is the western cyclones, and the western cyclone frequency is positively associated with $\delta^{18} \mathrm{O}$ isotopic content. Deuterium excess values in related firn-core accumulation layers ranged from $7 \%$ to $12 \%$. Strong depletion in $\delta^{18} \mathrm{O}$ and in d-excess records is associated with synoptic patterns of northwestern and ultra-polar cyclones that bring moisture from Arctic oceanic areas, and contributed similar accumulation to the spring, summer and autumn seasonal layers. Increased development of stationary cyclones is associated with $\delta^{18} \mathrm{O}$ enrichment and $\mathrm{d}$-excess depletion in firn-core accumulation layers. Stationary cyclones bring easternoriginated precipitation from the Pacific Ocean to the Altai glaciers.

The interior moisture sources contributed the remaining $33 \%$ of annual precipitation. These data are in reasonable agreement with recent findings by Kurita and others (2004) that more than half of the summer moisture forming the precipitation in Siberian plain stations originates from land surfaces. High d-excess values (up to $25.6 \%$ ) are associated with precipitation carried by southwestern cyclones and are a result of re-evaporating water vapor from internal moisture sources (e.g. Caspian and Aral Seas) with observed low air humidity. Their movement northward over the cold Asian continent and mixing with cool air masses resulted in strong $\delta^{18} \mathrm{O}$ depletion.

The technique developed here will be used for climatic and environmental reconstruction of snow accumulation, moisture origin and atmospheric circulation in north-central Asia over recent centuries, from oxygen isotope and deuterium records recovered from a $176 \mathrm{~m}$ surface-tobottom ice core obtained in 2003 from the Belukha snow/ firn plateau.

\section{ACKNOWLEDGEMENTS}

This research was supported by the US Department of Energy (DE-A107) and the Research Institute for Humanity and Nature, Kyoto, Japan. The authors thank T. Prokopinskaya for her inestimable contribution in organizing our expeditions. We also thank all the members of our expeditions: A. Lushnikov, A. Chebotarev, A. Surazakov, S. Polesskiy, M. Yoshihiro and M. Kenichiro, and V. Yakubovskiy and V. Podoprigora, the chief pilots of Russian helicopter MI-MTV from Altai Regional Rescue Department. For valuable comments and corrections we thank C.S.L. Ommanney, V. Masson-Delmotte, D. Peel, B.M. Vinther, D.R. Joswiak and an anonymous reviewer.

\section{REFERENCES}

Aizen, V.B., E. Aizen, J. Melack and T. Martma. 1996. Isotopic measurements of precipitation on central Asia glaciers (southeastern Tibetan, northern Himalayas, central Tien Shan). J. Geophys. Res., 101(D4), 9185-9196.

Aizen, V.B., E.M. Aizen, J.M. Melack, K.J. Kreutz and L.D. Cecil. 2004. Association between atmospheric circulation patterns and firn-ice core records from the Inilchek glacierized area, central Tien Shan. J. Geophys. Res., 109(D8, D08304). (10.1029/ 2003JD003894.)

Aizen, V.B., E.M. Aizen, D. Joswiak, K. Fujita, L.N. Takeuchi and S.A. Nikitin. In press. Climatic and atmospheric circulation pattern variability from ice-core isotope/geochemistry records (Altai, Tien Shan, Tibet). Ann. Glaciol.

Araguás-Araguás, L., K. Froehlich and K. Rozanski. 1998. Stable isotope composition of precipitation over southeast Asia. J. Geophys. Res., 103(D22), 28,721-28,742.

Barlow, L.K., J.W.C. White, R.G. Barry, J.C. Rogers and P. Grootes. 1993. The North Atlantic oscillation signature in deuterium and deuterium excess signals in the Greenland Ice Sheet Project 2 ice core, 1840-1970. Geophys. Res. Lett., 20(24), 2,901-2,904.

Ciais, P. and J. Jouzel. 1994. Deuterium and oxygen 18 in precipitation: isotopic model, including mixed cloud processes. J. Geophys. Res., 99(D8), 16,793-16,803.

Ciais, P., J.W.C. White, J. Jouzel and J.R. Petit. 1995. The origin of present-day Antarctic precipitation from surface snow deuterium excess data. J. Geophys. Res., 100(D9), 18,917-18,927.

Clark, I.D. and P. Fritz. 1997. Environmental isotopes in hydrogeology. Boca Raton, FL, Lewis Publishers.

Clausen, H.B. and 6 others. 1997. A comparison of the volcanic records over the past 4000 years from the Greenland Ice Core Project and Dye 3 Greenland ice cores. J. Geophys. Res., 102(C12), 26,707-26,723

Craig, H. 1957. Isotopic standards for carbon and oxygen and correction factors for mass-spectrometric analysis of carbon dioxide. Geochim. Cosmochim. Acta, 12, 133-149.

Craig, H. 1961. Isotopic variations in meteoric waters. Science, 133(3465), 1702-1703.

Dansgaard, W. 1964. Stable isotopes in precipitation. Tellus, 16(4), 436-468.

Dansgaard, W. and 10 others. 1993. Evidence for general instability of past climate from a 250-kyr ice-core record. Nature, 364(6434), 218-220.

De Angelis, M., J. Simoes, H. Bonnaveira, J.D. Taupin and R.J. Delmas. 2003. Volcanic eruptions recorded in the Illimani ice core (Bolivia): 1918-1998 and Tambora periods. Atmos. Chem. Phys. Discuss., 3, 2427-2463.

Easterling, D.R., T.C. Peterson and T.R. Karl. 1995. On the development and use of homogenized climate data sets. In Muircheartaigh, I.O., ed. Sixth International Meeting on Statistical Climatology, 19-23 June 1995, Galway, Ireland. Galway, University College, 435-438.

Friedman, I., A.C. Redfield, B. Shoen and J. Harris. 1964. The variations of the deuterium content of natural waters in the hydrological cycle. Rev. Geophys., 2, 177-224.

Froehlich, K., J.J. Gibson and P.K. Aggarwal. 2002. Deuterium excess in precipitation and its climatological significance. In Study of environmental change using isotope techniques. Vienna, International Atomic Energy Agency, 54-65.

Galakhov, V.P. 1981. Raschet i analys vodno-lednikovogo balanca v central'nom Altae, Katun chrebet. (PhD thesis, Akademii Nauk SSSR.)

Gat, J.R. and I. Carmi. 1987. Effect of climate changes on the precipitation patterns and isotopic composition of water in a climate transition zone: case of the Eastern Mediterranean Sea area. In Solomon, S.I., M. Beran and W. Hogg, eds., The Influence of Climatic Change and Climate Variability on the Hydrologic Regime and Water Resources. Wallingford, Oxon., International Association of Hydrological Sciences, 513-523. (IAHS Publication 168.

Gat, J.R. and W. Dansgaard. 1972. Stable isotope survey of the freshwater occurrences in Israel and the Jordan Rift Valley. J. Hydrol., 16, 177-211. 
Glukh, I.S. and N.K. Kononova. 1982. Relationship of long-term precipitation variability in western Siberia and Middle Asia. News of Academy of Science, Geogr. Ser., 3, 23-29.

Hammer, C.U., H.B. Clausen, W. Dansgaard, N. Gundestrup, S.J. Johnsen and N. Reeh. 1978. Dating of Greenland ice cores by flow models, isotopes, volcanic debris, and continental dust. J. Glaciol., 20(82), 3-26.

Hoffmann, G., M. Werner and M. Heimann. 1998. Water isotope module of the ECHAM atmospheric general circulation model: a study on timescales from days to several years. J. Geophys. Res., 103(D14), 16,871-16,896.

Hoffmann, G., J. Jouzel and V. Masson. 2000. Stable water isotopes in atmospheric general circulation models. Hydrol. Process., 14, 1385-1406.

Holdsworth, G. and H.R. Krouse. 2002. Altitudinal variation of the stable isotopes of snow in regions of high relief. J. Glaciol., 48(160), 31-41.

Johnsen, S.J. 1977. Stable isotope homogenization of polar firn and ice. In Isotopes and Impurities in Snow and Ice. Wallingford, Oxon., International Association of Hydrological Sciences, 210219. (IAHS Publication 118.)

Jouzel, J. and L. Merlivat. 1984. Deuterium and oxygen 18 in precipitation: modeling of the isotopic effect during snow formation. J. Geophys. Res., 89(D7), 11,749-11,757.

Jouzel, J., R.D. Koster, R.J. Suozzo and G.L. Russell. 1994. Stable water isotope behavior during the last glacial maximum: a general circulation model analysis. J. Geophys. Res., 99(D12), $25,791-25,802$.

Jouzel, J. and 12 others. 1997. Validity of the temperature reconstruction from water isotopes in ice cores. J. Geophys. Res., 102(C12), 26,471-26,487.

Kendall, C. and J.J. McDonnell. 1998. Isotope tracers in catchment hydrology. New York, Elsevier.

Koerner, R.M. and D.A. Fisher. 1990. A record of Holocene summer climate from a Canadian high-Arctic ice core. Nature, 343(6259), 630-631.

Kotlyakov, V.M. 1997. Atlas snezhno-ledovykh resursa mira. Moscow, Russian Academy of Sciences. Institute of Geography.

Kreutz, K.J., V.B. Aizen, L.D. Cecil and C.P. Wake. 2001. Oxygen isotopic and soluble ionic composition of a shallow firn core, Inilchek glacier, central Tien Shan. J. Glaciol., 47(159), 548-554.

Kreutz, K.J., C.P. Wake, V.B. Aizen, L.D. Cecil and H.A. Synal. 2003. Seasonal deuterium excess in a Tien Shan ice core: influence of moisture transport and recycling in Central Asia. Geophys. Res. Lett., 30(18), 1922. (10.1029/2003GL017896.)

Kurita, N., N. Yoshida, G. Inoue and E.A. Chayanova. 2004. Modern isotope climatology of Russia: a first assessment. J. Geophys. Res., 109(D3), D03102. (10.1029/2003JD003404.)

Kuznezova, L.P., ed. 1984. Soderjanie i perenos vlagi v atmosphere nad territoriei SSSR. Moscow, Main Department of Geodesy and Mapping Survey, USSR.

Merlivat, L. and J. Jouzel. 1979. Global climatic interpretation of the deuterium-oxygen 18 relationship for precipitation. J. Geophys. Res., 84(C8), 5029-5033.
Morrison, J., T. Brockwell, T. Merren, F. Fourel and A.M. Philips. 2001. On-line high-precision stable hydrogen isotopic analyses on nanoliter water samples. Analyt. Chem., 73(15), 3570-3575.

Naftz, D.L. and 6 others. 2002. Ice core evidence of rapid air temperature increases since 1960 in alpine areas of the Wind River Range, Wyoming, United States. J. Geophys. Res., 107(D13), 4171. (10.1029/2001JD000621.)

Narojniy, U.K., O.V. Narojnaya and K.I. Popova. 1993. Cyrculacionniy regime i gidrotermicheskie usloviya zim Altaya. Glaciologiya Altaya, 4(19), 183-188.

Olivier, S. and 10 others. 2003. Glaciochemical investigation of an ice core from Belukha Glacier, Siberian Altai. Geophys. Res. Lett., 30(19), 2019. (10.1029/2003GL018290.)

Petit, J.R. and 18 others. 1999. Climate and atmospheric history of the past 420,000 years from the Vostok ice core, Antarctica. Nature, 399(6735), 429-436.

Popova, K.I. 1972. O tipah godovogo hoda atmosphernich osadkov v Gornom Altae. Glaciologiya Altaya, 7, 169-174.

Schotterer, U., K. Fröhlich, H.W. Gäggeler, S. Sandjordj and W. Stichler. 1996. Isotope records from Mongolian and alpine ice cores as climate indicators. Climatic Change, 36, 519-530.

Schwander, J., J. Jouzel, C.U. Hammer, J.R. Petit, R. Udisti and E. Wolff. 2001. A tentative chronology for the EPICA Dome Concordia ice core. Geophys. Res. Lett., 28(22), 4,243-4,246.

Shuman, C.A., R.B. Alley, S. Anandakrishnan, J.W.C. White, P.M. Grootes and C.R. Stearns. 1995. Temperature and accumulation at the Greenland Summit: comparison of high-resolution isotope profiles and satellite passive microwave brightness temperature trends. J. Geophys. Res., 100(D5), 9,165-9,177.

Soden, B.J., R.T. Wetherald, G.L. Stenchikov and A. Robock. 2002. Global cooling after the eruption of Mount Pinatubo: a test of climate feedback by water vapor. Science, 296(5568), 727-730.

Thompson, L.G. and 6 others. 1995. A 1000 year climatic ice-core record from the Guliya ice cap, China: its relationship to global climate variability. Ann. Glaciol., 21, 175-181.

Tian, L., V. Masson-Delmotte, M. Stievenard, T. Yao and J. Jouzel. 2001. Tibetan Plateau summer monsoon northward extent revealed by measurements of water stable isotopes. J. Geophys. Res., 106(D22), 28,081-28,088.

Vimeux, F., V. Masson, J. Jouzel, M. Stiévenard and J.R. Petit. 1999. Glacial-interglacial changes in ocean surface conditions in the Southern Hemisphere. Nature, 398(6726), 410-413.

Welker, J.M. 2000. Isotopic $\delta^{18} \mathrm{O}$ characteristics of weekly precipitation collected across the USA: an initial analysis with applications to water source studies. Hydrol. Process., 14, 1449-1464.

Yao, T. and L.G. Thompson. 1992. Trends and features of climatic changes in the past 5000 years recorded by the Dunde ice core. Ann. Glaciol., 16, 21-24.

Yao, T., V. Masson, J. Jouzel, M. Stiévenard, W. Sun and K. Jiao. 1999. Relationship between $\delta^{18} \mathrm{O}$ in precipitation and surface air temperature in the Ürümqi river basin, east Tianshan mountains, China. Geophys. Res. Lett., 26(23), 3473-3476.

Zielinski, G.A., P.A. Mayewski, L.D. Meeker, S.I. Whitlow and M.S. Twickler. 1996. 110,000-yr record of explosive volcanism from the GISP2 (Greenland) ice core. Quat. Res., 45(2), 109-118. 


\section{APPENDIX}

Table 6. Synoptic processes observed over western Siberia (WS) (Popova, 1972; Narojniy and others 1993)

\begin{tabular}{|c|c|c|c|c|c|c|}
\hline Type & Sub-types & \multicolumn{2}{|c|}{ General description } & Precipitation (origin) & Troposphere & At surface \\
\hline $\begin{array}{l}\text { Western } \\
\text { anticyclones } \\
\text { (WA) }\end{array}$ & $\begin{array}{l}W_{a} \\
W_{b} \\
W_{c}\end{array}$ & \multicolumn{2}{|c|}{$\begin{array}{l}\text { Cyclones transfer over WS plain } \\
\text { Anticyclogenesis develops over WS } \\
\text { Cyclones develop at two fronts and } \\
\text { moisture is intensively advected with } \\
\text { westerlies }\end{array}$} & $\begin{array}{l}\text { Possible } \\
\text { Possibly intensive in } \\
\text { the Altai (Atlantic) }\end{array}$ & Westerlies developing & $\begin{array}{l}\text { Anticyclonic fields de- } \\
\text { veloping over the Altai } \\
\text { and sub-mountain }\end{array}$ \\
\hline $\begin{array}{l}\text { Western } \\
\text { cyclones (WC) }\end{array}$ & $W C_{b}$ & \multicolumn{2}{|c|}{$\begin{array}{l}W_{\mathrm{a}} \text { extend over the Altai, Kazakhstan } \\
\text { and WS plain. Thunderstorms develop } \\
\text { in summer } \\
\text { Anticyclones transfer at the north from } \\
\text { the Altai }\end{array}$} & $\begin{array}{l}\text { Intensive, especially } \\
\text { in mountains (Atlantic) }\end{array}$ & $\begin{array}{l}\text { Westerlies affected by } \\
\text { stationary waves with } \\
\text { large amplitude }\end{array}$ & $\begin{array}{l}\text { WCs transferring at } \\
\text { southern WS and } \\
\text { northern Kazakhstan }\end{array}$ \\
\hline $\begin{array}{l}\text { Northwestern } \\
\text { anticyclones } \\
\text { (NWA) }\end{array}$ & \multirow[t]{2}{*}{$\mathrm{NWA}_{\mathrm{b}}$} & \multirow[t]{2}{*}{$\begin{array}{l}\text { Intensification } \\
\text { of arctic front }\end{array}$} & $\begin{array}{l}\text { Anticyclogenesis develops } \\
\text { to north and west from the } \\
\text { Altai; dry and cold weather } \\
\text { There are pressure } \\
\text { spaces to the east and } \\
\text { northeast from the Altai, } \\
\text { cloudy and windy weather } \\
\text { over the eastern Altai }\end{array}$ & $\begin{array}{l}\text { No } \\
\text { Insignificant at the } \\
\text { eastern Altai }\end{array}$ & $\begin{array}{l}\text { Northwesterly air mass } \\
\text { transferring over WS } \\
\text { and eastern Kazakhstan }\end{array}$ & $\begin{array}{l}\text { Anticyclones develop- } \\
\text { ing over the Altai }\end{array}$ \\
\hline $\begin{array}{l}\text { Northwestern } \\
\text { anticyclones } \\
\text { (NWC) }\end{array}$ & & & $\begin{array}{l}\text { Arctic air masses are } \\
\text { transferred in rear of } \\
\text { cyclones intensifying } \\
\text { during their passage over } \\
\text { the mountains during } \\
\text { spring and summer }\end{array}$ & $\begin{array}{l}\text { Intensive especially } \\
\text { in mountains (North } \\
\text { Atlantic-Arctic) }\end{array}$ & $\begin{array}{l}\text { Upper trough over NS } \\
\text { and wedge over } \\
\text { Europe }\end{array}$ & $\begin{array}{l}\text { Transferring NWCs over } \\
\text { WS }\end{array}$ \\
\hline $\begin{array}{l}\text { Southwestern } \\
\text { anticyclones } \\
\text { (SWA) }\end{array}$ & $\mathrm{SWA}_{\mathrm{a}}$ & \multicolumn{2}{|l|}{$\begin{array}{l}\text { Front part of } \\
\text { upper trough } \\
\text { is located over } \\
\text { Altai and } \\
\text { southeast of } \\
\text { WS. } \\
\text { Southwestern } \\
\text { heat advection }\end{array}$} & $\begin{array}{l}\text { No. Heat advection } \\
\text { from south, cloudy } \\
\text { weather, possible } \\
\text { moderate droughts } \\
\text { with humidity }<40 \%\end{array}$ & $\begin{array}{l}\text { Flat pressure trough } \\
\text { over Europe, and flat } \\
\text { wedge over WS with } \\
\text { axis from the Altai to } \\
\text { Laptev Sea }\end{array}$ & $\begin{array}{l}\text { Cyclonic fields over } \\
\text { central Kazakhstan } \\
\text { southeast WS } \\
\text { Anticyclonic fields over } \\
\text { the Altai, Kazakhstan, } \\
\text { south WS }\end{array}$ \\
\hline $\begin{array}{l}\text { Southwestern } \\
\text { anticyclones } \\
\text { (SWC) }\end{array}$ & & & $\begin{array}{l}\text { SWC intrusions from } \\
\text { Caspian, Aral, Black Seas } \\
\text { to southeast of WS and } \\
\text { the Altai. Overcast } \\
\text { weather, with possible } \\
\text { thunderstorms }\end{array}$ & $\begin{array}{l}\text { May be intensive. } \\
\text { (Caspian, Aral, } \\
\text { Black seas) }\end{array}$ & $\begin{array}{l}\text { Trough with axis } \\
\text { located from mouth } \\
\text { of Ob' river to } \\
\text { southwest of WS }\end{array}$ & \\
\hline $\begin{array}{l}\text { Ultra-polar } \\
\text { intrusion (UP) }\end{array}$ & & \multicolumn{2}{|c|}{$\begin{array}{l}\text { Arctic air from Kara Sea and Taimir is } \\
\text { transferred in rear of NWCs as anticyclones }\end{array}$} & $\begin{array}{l}\text { Intensive before cold } \\
\text { snap in warm season } \\
\text { (Arctic) }\end{array}$ & $\begin{array}{l}\text { Meridional isohypse; } \\
\text { wedge over northern } \\
\text { seas, high cyclone } \\
\text { over Yakutia, trough } \\
\text { over southern WS } \\
\text { and Kazakhstan, } \\
\text { northeasterly winds } \\
\text { over WS }\end{array}$ & $\begin{array}{l}\text { Westerly and } \\
\text { northwesterly winds } \\
\text { over the Altai }\end{array}$ \\
\hline $\begin{array}{l}\text { Stationary } \\
\text { cyclone (StCyc) }\end{array}$ & & \multicolumn{2}{|c|}{$\begin{array}{l}\text { Development of high thermobaric field } \\
\text { causes formation of quasi-stationary } \\
\text { cyclone. Location of Arctic front outside } \\
\text { cyclone causes stationary cyclone. Passing } \\
\text { of the secondary fronts cause development } \\
\text { of thunderstorms (in summer), overcast and } \\
\text { cloudy weather }\end{array}$} & $\begin{array}{l}\text { Intensive summer } \\
\text { cloudburst and } \\
\text { snowfalls (eastern, } \\
\text { e.g. Pacific or local } \\
\text { convective) }\end{array}$ & $\begin{array}{l}\text { StCyc developing in } \\
\text { the right through } \\
\text { thermobaric field }\end{array}$ & $\begin{array}{l}\text { Isolation of cold air } \\
\text { masses over southeast } \\
\text { regions of WS }\end{array}$ \\
\hline
\end{tabular}

